\title{
Multiannual observations and modelling of seasonal thermal profiles through supraglacial debris in the Central Himalaya
}

\author{
Ann V. Rowan ${ }^{1 *}$, Lindsey I. Nicholson ${ }^{2}$, Emily Collier ${ }^{3}$, Duncan J. Quincey ${ }^{4}$, Morgan J. \\ ${ }^{3}$ Climate System Research Group, Institute of Geography, Friedrich-Alexander-University Erlangen- \\ Nürnberg (FAU), Germany \\ ${ }^{4}$ School of Geography, University of Leeds, LS2 9JT, UK \\ ${ }^{5}$ Department of Geography and Earth Sciences, Aberystwyth University, SY23 3DB, UK \\ ${ }^{6}$ University of Grenoble Alpes, CNRS, IRD, Grenoble-INP, IGE, F-38000 Grenoble, France \\ ${ }^{7}$ Geophysical Institute, University of Alaska Fairbanks, Fairbanks, Alaska, USA \\ ${ }^{8}$ College of Science, Swansea University, Singleton Park, Swansea, SA2 8PP, UK \\ ${ }^{9}$ Department of Geology, University Centre in Svalbard, 9171 Longyearbyen, Norway \\ *Correspondence to A. Rowan (a.rowan@sheffield.ac.uk)

\begin{abstract}
Many glaciers in the Central Himalaya are covered with rock debris that modifies the transfer of heat from the atmosphere to the underlying ice. These debris-covered glaciers are experiencing rapid mass loss at rates that have accelerated during the last two decades. Quantifying recent and future glacier mass change requires understanding the relationship between debris thickness and ablation particularly through the summer monsoon season. We present air, near-surface and debris temperatures measured during three monsoon seasons at five sites on Khumbu Glacier in Nepal, and compare these results to similar measurements from two other debris-covered glaciers in this region. Seasonal debris temperature profiles are approximately linear and consistent between sites for thick $(>0.5 \mathrm{~m})$ and thin $(<0.5 \mathrm{~m})$ debris across thicknesses ranging from 0.26 to $2.0 \mathrm{~m}$. The similarities between these multiannual data imply that they are representative of supraglacial debris layers in the monsooninfluenced Himalaya more generally. We compare three methods to calculate sub-debris ablation, including using our temperature measurements with a thermal diffusion model that incorporates a simplified treatment of debris moisture. Estimated ablation between 3 June and 11 October at around $5000 \mathrm{~m}$ above sea level ranged from $0.10 \mathrm{~m}$ water equivalent beneath $1.5 \mathrm{~m}$ of debris to $0.47 \mathrm{~m}$ water
\end{abstract}


The Cryosphere Discuss., https://doi.org/10.5194/tc-2017-239

Manuscript under review for journal The Cryosphere

Discussion started: 30 November 2017

(c) Author(s) 2017. CC BY 4.0 License.

equivalent beneath $0.3 \mathrm{~m}$ debris. However, these values are small when compared to remotely observed rates of surface lowering, suggesting that mass loss from these debris-covered glaciers is greatly enhanced by supraglacial and englacial processes that locally amplify ablation.

\section{Introduction}

Climate change is having a dramatic and spatially-variable impact on Himalayan glaciers (Yao et al., 2012; Brun et al. 2017) with consequences for regional hydrological budgets (Immerzeel et al., 2010) and glacial hazard potential (Benn et al., 2012; Westoby et al., 2014). Although predictions have been made for $21^{\text {st }}$ Century atmospheric warming in central Asia, the likely response of glaciers to climate change is difficult to quantify precisely (e.g. Bolch et al., 2012; Kraaijenbrink et al., 2017) due to the strong feedbacks between high relief topography, orographic weather systems, glacier dynamics and extensive supraglacial debris (e.g. Bookhagen and Burbank, 2010; Scherler et al. 2011; Rowan et al., 2015). In tectonically active mountain ranges such as the Himalaya, rapid rock uplift and surface processes (e.g. glacial and periglacial erosion and mass movement) result in large sediment fluxes from surrounding hillslopes to glacier surfaces. Rock debris is incorporated and transported englacially to the ablation area where it melts out to form a supraglacial debris layer (Scherler et al., 2011). In the Himalaya, about $13 \%$ of the glacierised area (Kääb et al., 2012) and over $40 \%$ of the ice mass in ablation areas is debris covered (Kraaijenbrink et al., 2017). In the Everest region 25-36\% of the glacierised area is debris covered (Ragettli et al., 2015; Thakuri et al., 2014; Vincent et al., 2016). Debris thicknesses exceeding $2.0 \mathrm{~m}$ are common on the lower parts of these glaciers (McCarthy et al., 2017; Nicholson and Benn, 2013). A general trend of glacier mass loss during the last century (Bolch et al., 2012) has reduced glacier volumes and velocities (Quincey et al., 2009) promoting the thickening and expansion of supraglacial debris (Thakuri et al., 2014).

Supraglacial debris modifies the impact of atmospheric warming on glacier mass balance by changing the distribution and magnitude of ablation of the underlying ice (Nicholson and Benn, 2006; Østrem, 1959). The empirical relationship between debris thickness and ablation is referred to as the Østrem curve (Østrem, 1959); where debris is patchy or thin, ablation can be greater than that for a clean-ice surface, due to efficient heat transfer through the debris and the lower albedo of rock debris compared to clean ice. Once debris reaches an effective thickness the gradient of the Østrem curve reverses and ablation decreases as insulation of the ice increases with debris thickness (Brock et al., 2010; Mihalcea et al., 2006; Nicholson and Benn, 2006; Reid et al., 2012). The properties of the debris layer in addition to its thickness also modify thermal transfer; numerical experiments for Miage Glacier in the Italian Alps showed that the moisture content and latent heat flux of debris layers affect ablation, with moist debris reducing ablation compared to dry debris, mainly due to heat extraction by the latent heat flux (Collier et al., 2014). 
The Cryosphere Discuss., https://doi.org/10.5194/tc-2017-239

Manuscript under review for journal The Cryosphere

Discussion started: 30 November 2017

(c) Author(s) 2017. CC BY 4.0 License.

Glacier mass change can be estimated from multi-temporal satellite observations of surface lowering where emergence velocities are known. These observations indicate accelerating mass change in the Everest region from $-0.32 \pm 0.08$ m water equivalent (w.e.) $\mathrm{a}^{-1}$ between 1970-2007 (Bolch et al., 2011) to $-0.58 \pm 0.19 \mathrm{~m}$ w.e. $\mathrm{a}^{-1}$ between $2000-2015$ (King et al., 2017). Other studies based on remotely sensed data have observed similar rates of mass loss between debris-covered and clean-ice glaciers (e.g. Kääb et al. 2012). This anomalous behaviour could be explained by the enhancement of ablation at ice cliffs within the debris-covered ablation area (e.g. Gardelle et al., 2013; Immerzeel et al., 2013). However, studies made at the glacier or catchment scale show a different trend. A recent survey of the mass balance of debris-covered Changri Nup Glacier in the Everest region demonstrated that mass loss from a debris-covered glacier surface in the absence of exposed ice cliffs was about $50 \%$ of that from an equivalent clean-ice glacier (Vincent et al., 2016). Hydrological modelling of glacier mass change in the Langtang region of Nepal suggests a loss of $35-55 \%$ of the glacierised area by 2100 , but only $25-33 \%$ loss of debris-covered glacier area over the same period (Rageletti et al., 2016). These conflicting results demonstrate that the spatial variability of supraglacial debris thickness needs to be incorporated into calculations of glacier-wide and regional mass balance.

Across the majority of the glacierised area in the Everest region, supraglacial debris thickness significantly exceeds the few centimetres that control the change between between ablation enhancement and ablation reduction (Østrem, 1959). However, ablation beneath supraglacial debris is challenging to measure directly (e.g. Vincent et al. 2016; Rounce et al., 2015). Stake measurements are only representative of point mass balance, and difficult to extrapolate across the ablation area due to high spatial variability in debris thickness that promotes differential ablation (Benn et al., 2012). We therefore seek a method to calculate ablation from other variables such as debris thickness, air temperature and debris temperature (e.g. Collier et al., 2014; Nicholson and Benn, 2013; Rounce et al., 2015) particularly as progress is being made towards accurately constraining these variables from remote observations (e.g. Mihalcea et al., 2008; Rounce and McKinney, 2014).

In this study, we measured near-surface air temperatures as well as temperatures through debris layers of varying thicknesses at a number of locations on Khumbu Glacier in the Everest region of Nepal during the 2014, 2015 and 2016 monsoon seasons (May-October). The thermal properties of the debris revealed by these measurements were compared with previous work at Khumbu Glacier (Kayastha et al., 2000) and at two other glaciers in the Everest region $\left(27.5^{\circ} \mathrm{N}, 86.6^{\circ} \mathrm{E}\right), \mathrm{Ngozumpa}$ and Imja-Lhotse Shar Glaciers. Ablation was calculated using our observations with a positive degree-day approach, a downward heat flux method, and a numerical model that explicitly treats heat diffusion through supraglacial debris (Collier et al., 2014). We compared our calculated ablation values with stake 
The Cryosphere Discuss., https://doi.org/10.5194/tc-2017-239

Manuscript under review for journal The Cryosphere

Discussion started: 30 November 2017

(c) Author(s) 2017. CC BY 4.0 License.

measurements where available and surface lowering observations to quantify the contribution of subdebris ablation to glacier-wide mass loss.

\section{Debris cover and ablation at Khumbu Glacier}

\subsection{Khumbu Glacier}

Khumbu Glacier (Fig. 1) is a large debris-covered glacier $15.4 \mathrm{~km}$ long with an area of $19.1 \mathrm{~km}^{2}$ (not including the detached tributaries Changri Nup and Changri Shar Glaciers; $11.4 \mathrm{~km}^{2}$ ), with altitudes ranging from 4,926 $\mathrm{m}$ to 7,870 $\mathrm{m}$ above sea level with a median of 5,610 $\mathrm{m}$ (RGI Consortium, 2017). Khumbu Glacier flows westward from the southern and eastern slopes of Mt. Everest and Lhotse, and turns to the south after the icefall, within which the equilibrium line is located (Benn and Lehmkuhl, 2000; Inoue, 1977). The debris layer is several metres thick near the terminus and generally thins upglacier to the base of the icefall (Nakawo et al., 1986). The grain size of the supraglacial debris ranges from boulders many metres in diameter to fine sand and silt (Fig. 2). Velocity is variable along the length of the glacier; maximum velocity of up to $70 \mathrm{~m} \mathrm{a}^{-1}$ occurs below the icefall while the lowermost 4-5 km of the glacier appears to be stagnant or slow flowing (observed annual flow is less than the 15 $\mathrm{m}$ pixel size of the satellite image) through the debris-covered section (Quincey et al., 2009) and any movement is likely due to deformation of the ice (Watson et al., 2017). The glacier surface 5-6 km from the terminus has developed high relief associated with differential ablation, which is more pronounced on the true left where there are numerous ice cliffs and supraglacial ponds; supraglacial lake area is expanding but is less developed than similar systems found at Ngozumpa and Imja-Lhotse Shar Glaciers (Watson et al., 2017).

\subsection{Supraglacial debris thickness}

Supraglacial debris thickness on Khumbu Glacier varies from a continuous thin (defined here as $<0.5$ $\mathrm{m})$ coverage to several metres thick. Thin, patchy debris is only found in the relatively narrow transition zone between the clean ice of the accumulation area and the heavily debris-covered ablation area. An estimate of debris thickness made in 1978 from observations of debris overlying ice cliffs was 0.5-2 m across the entire debris-covered surface and increased exponentially down-glacier to reach greater than $2 \mathrm{~m}$ thick near the terminus $(n=50)$ (Nakawo et al., 1986). Measurements made in 2014 by excavation of the debris layer ranged up to $3.0 \mathrm{~m}$ with a mean value of $0.35 \mathrm{~m}(n=64)$ (Soncini et al., 2016). Our measurements, made in 2014 by excavation, estimated that $80 \%$ of the area between the terminus and $3.5 \mathrm{~km}$ upglacier was covered with debris greater than $1 \mathrm{~m}$ thick $(n=143)$ with thinner $(0.04-1.0 \mathrm{~m})$ debris observed at the perimeter of supraglacial ponds or on the top of ice cliffs. Debris was thickest in the southwest of the lower ablation area within $1.5 \mathrm{~km}$ of the terminal moraine, with thinner debris along the eastern margin of the lower ablation area around a network of supraglacial ponds. 
The Cryosphere Discuss., https://doi.org/10.5194/tc-2017-239

Manuscript under review for journal The Cryosphere

Discussion started: 30 November 2017

(c) Author(s) 2017. CC BY 4.0 License.

\subsection{Mass balance}

Mass balance measurements using ablation stakes in experimental plots in the upper ablation area on Khumbu Glacier were made by Kayastha et al. (2000) in August 1974 and August 1976. The estimated loss of ice across the debris-covered area was up to $6.5 \mathrm{~mm}$ w.e. day ${ }^{-1}$ depending on debris thickness. Four stake measurements were made at two sites between 5050-5240 m during 12 periods between 8 May and 9 October 2014 beneath debris $0.01-0.09 \mathrm{~m}$ thick, which gave ablation ranging from $12.3 \mathrm{~mm}$ w.e. day ${ }^{-1}$ to $21.4 \mathrm{~mm}$ w.e. day ${ }^{-1}$ (Soncini et al., 2016). Taking the mid-point of this range and extrapolating the daily value to the entire measurement period gives ablation of $-2.60 \mathrm{~m}$ w.e. $\mathrm{a}^{-1}$. On Changri Nup Glacier at 5470 m, 13 ablation stake measurements were made from November 2014 to November 2015 through artificially constructed debris thicknesses of $0 \mathrm{~m}$ to $0.41 \mathrm{~m}$ and recorded mass balance values of -1.35 to $-1.98 \mathrm{~m}$ w.e. $\mathrm{a}^{-1}$ (Vincent et al., 2016). Applying a continuity equation over the debris-covered tongue of Changri Nup Glacier, Vincent et al. (2016) showed that the area-averaged ablation was strongly reduced by the debris cover compared with an equivalent clean-ice glacier.

Degree day factors (DDFs) calculated previously for Khumbu Glacier using measurements collected over 12 days in late May were $11.1 \mathrm{~mm}$ w.e. ${ }^{\circ} \mathrm{C}^{-1}$ day ${ }^{-1}$ beneath $0.1 \mathrm{~m}$ of debris, $5.3 \mathrm{~mm}$ w.e. ${ }^{\circ} \mathrm{C}^{-1}$ day $^{-1}$ beneath $0.4 \mathrm{~m}$ of debris, and $16.9 \mathrm{~mm}$ w.e. ${ }^{\circ} \mathrm{C}^{-1}$ day $^{-1}$ for clean ice (Fig. 3; Kayastha et al., 2000). These measurements indicated greater ablation than that observed beneath similar debris thicknesses at Koxkar Glacier in the Tien Shan (Juen et al., 2014) and Belvedere Glacier in the Italian Alps (Nicholson and Benn, 2006), and were higher than the mean clean-ice DDF of $9.3 \mathrm{~mm}$ w.e. ${ }^{\circ} \mathrm{C}^{-1}$ day ${ }^{-1}$ for Glacier AX010 measured over three summer months at altitudes between 4950 and $5250 \mathrm{~m}$, and clean-ice DDF for Lirung and Raikot Glaciers of $6.6 \mathrm{~mm}$ w.e. ${ }^{\circ} \mathrm{C}^{-1}$ day ${ }^{-1}$ (Kayastha et al., 2000). For comparison, DDFs measured at Chhota Shigri Glacier in the Indian Himalaya between 4300 and 4900 m were $3.34 \pm 0.20 \mathrm{~mm}$ w.e. ${ }^{\circ} \mathrm{C}^{-1}$ day ${ }^{-1}$ for debris cover, $5.28 \pm 0.14 \mathrm{~mm}$ w.e. ${ }^{\circ} \mathrm{C}^{-1}$ day ${ }^{-1}$ for snow, and $8.63 \pm 0.18 \mathrm{~mm}$ w.e. ${ }^{\circ} \mathrm{C}^{-1}$ day $^{-1}$ for ice $(n=192 ; 22$ from the debris-covered section) (Azam et al., 2014).

\section{Methods}

This section describes the field-data collection methods used in this study at five sites on Khumbu Glacier (KH1-5). Similar methods were used at two sites on Ngozumpa Glacier (NG1 and NG2) and four sites on Imja-Lhotse Shar Glacier (IM4, IM11, IM13 and IM14).

\subsection{Off-glacier meteorological measurements}

Air temperature $\left(T_{a}\right)$, precipitation and snowfall were measured at the Pyramid Observatory adjacent to the tongue of Khumbu Glacier at 5035 m (Fig. 1) between 1997 and 2011. Precipitation was measured using a Geonor T-200BM sensor that captures all precipitation phases and corrected for snow undercatch following World Meteorological Office recommendations (Sherpa et al., 2017). 
The Cryosphere Discuss., https://doi.org/10.5194/tc-2017-239

Manuscript under review for journal The Cryosphere

Discussion started: 30 November 2017

(c) Author(s) 2017. CC BY 4.0 License.

\subsection{On-glacier air and debris temperature measurements}

We measured $T_{a}$, near-surface debris temperature $\left(T_{s}\right)$, and temperatures within the debris layer $\left(T_{d}\right)$ down to the debris-ice interface $\left(T_{i}\right)$ at four sites $(\mathrm{KH} 1-4)$ on Khumbu Glacier through the 2014 monsoon season. Further $T_{a}, T_{s}$ and $T_{d}$ data were collected using the same approach at KH1 through winter 2014/2015, and at KH2 and KH5, through 2015/16 (Table 1). All sites were located on gently inclined slopes offset from the crests of topographic highs where debris was less than a metre thick. At $\mathrm{KH} 1,2,3$ and 5, debris was dominated by light-coloured gneiss and leucogranite with minor schist fragments, whereas at KH4 debris contained gneiss and leucogranite but were generally darker and more angular due to a greater proportion of schist. The grain size of the debris ranged between coarse sand and decimetre-sized clasts, and was generally finer than the bulk grain size of the whole debris layer as sites were chosen where sections could be excavated rather than where metre-scale boulders occupied the glacier surface (Fig. 2). At KH3, redistribution of the debris by mass movement and collapse of the underlying ice began to exhume thermistors from within the debris after 3 June 2014. At KH4, the thermistor measuring $T_{a}$ malfunctioned on 12 October 2014 and measurements made after this time were discarded. At KH1, measurements continued through the winter until 20 October 2015, while KH2 was re-instrumented and KH5 was established nearby for 2015/16 (Table 1).

At each site, a vertical section was excavated and thermistors were placed within the exposed section at measured intervals between the debris surface and the debris-ice interface. The excavated debris was then replaced as close to the original condition as possible. The thermistors that measured $T_{s}$ were shielded from incoming shortwave radiation by covering them with debris about 0.02 thick. $T_{a}$ was measured using thermistors mounted in naturally ventilated radiation shields $1 \mathrm{~m}$ above the glacier surface at each site. All thermistors were connected to Gemini Tiny Tag Plus2 TGP-4520 dataloggers that have a stated accuracy of $\pm 0.4^{\circ} \mathrm{C}$, and temperature was sampled every 30 minutes. The manufacturer calibrated the equipment before use, and at the end of the data collection measurements at room temperature agreed within the stated accuracy. The location and altitude of each site was measured using a Garmin GPSmap 62s handheld unit, which has a stated accuracy of $\pm 5 \mathrm{~m}$ in the horizontal plane and $\pm 3 \mathrm{~m}$ in the vertical plane.

\subsection{Comparison with Ngozumpa and Imja-Lhotse Shar Glaciers}

Data collected from five sites on Khumbu Glacier between May 2014 and September 2016 were compared to those collected at two sites on Ngozumpa Glacier between November 2001 and October 2002 (Nicholson and Benn, 2013) and November 2014 and April 2016 (S. Thompson, unpublished data) and at four sites on Imja-Lhotse Shar Glacier between May and October 2014 (Rounce et al., 2015). These three debris-covered glaciers are located adjacent to each other and have several factors in 
The Cryosphere Discuss., https://doi.org/10.5194/tc-2017-239

Manuscript under review for journal The Cryosphere

Discussion started: 30 November 2017

(c) Author(s) 2017. CC BY 4.0 License.

common; their ablation areas are covered with extensive debris layers, composed of a mixture of clasts of leucogranite, sillimanite-grade gneiss and minor schist (Benn et al., 2012). Mean debris thickness measured at two sites within $7 \mathrm{~km}$ of the terminus of Ngozumpa Glacier in 2001 was $1.25 \pm 0.75 \mathrm{~m}(n=$ 218) (Nicholson and Benn, 2013) and on part of Imja-Lhotse Shar Glacier in 2013 was $0.42 \pm 0.29 \mathrm{~m}$ ( $n$ = 25) (Rounce and McKinney, 2014). The on-glacier $T_{a}, T_{s}, T_{d}$ and $T_{i}$ timeseries from these three glaciers do not always cover the same periods, with several weeks missing at the start or end of the monsoon season due to the timing of field visits. Any data gaps were excluded from analyses. All temperature data were compared using values for the monsoon season when the debris was unlikely to be snow covered (03 June to 11 October), as well as for summer (1 May to 31 October) and winter (1 November to 30 April).

Ngozumpa Glacier (Fig. 1) is the largest glacier in Nepal located $25 \mathrm{~km}$ to the west of Mt. Everest, with an area of $79.5 \mathrm{~km}^{2}$ and altitudes ranging from $4686 \mathrm{~m}$ to $8176 \mathrm{~m}$ with a median of $5698 \mathrm{~m}$ (RGI Consortium, 2017). The 18-km long glacier flows southward from cirques where most accumulation occurs by ice and snow avalanching, down to about $4659 \mathrm{~m}$. The lower $15 \mathrm{~km}$ of the glacier is covered in rock debris increasing in thickness to reach 1-3 m towards the terminus (Nicholson, 2005). Surface topography in the debris-covered glacial ablation area is highly irregular, with a typical local relief of 30-50 m, and ice cliffs exposed within this hummocky terrain account for only $5 \%$ of the surface area but $40 \%$ of the mass loss of the lower terminus (Thompson et al., 2016). $T_{d}$ was measured on Ngozumpa Glacier at two sites (Fig. 1); NG1 was a vertical profile through $0.75 \mathrm{~m}$ of typical diamictic debris that did not reach the debris-ice interface. Measurements were made every 30 minutes from November 2001 to October 2002 using Gemini thermistors and Tinytag Plus TGP-0073 loggers with a stated accuracy of $\pm 0.3^{\circ} \mathrm{C}$ at $0^{\circ} \mathrm{C}$. NG2 was a vertical profile through $1.8 \mathrm{~m}$ of debris at the surface of an ice cliff. Measurements were made using a Geoprecision thermistor array with a stated accuracy of $\pm 0.25^{\circ} \mathrm{C}$ from 30 November 2014 to 4 April 2016 at six hour intervals. The ice temperatures measured at NG2 are not analysed here but indicate temperate ice in the upper few metres of the glacier.

Imja-Lhotse Shar Glacier (Fig. 1) is a smaller debris-covered glacier located $12 \mathrm{~km}$ southeast of Khumbu Glacier with an area of $15.3 \mathrm{~km}^{2}$ that refers to both the northwest-flowing Imja Glacier and southwest-flowing Lhotse Shar Glacier that converge and terminate into a proglacial lake. Altitudes range from $5021 \mathrm{~m}$ to $7998 \mathrm{~m}$ with a median of $5469 \mathrm{~m}$ (RGI Consortium, 2017). There is extensive debris cover below $5200 \mathrm{~m}$ on Imja Glacier and below $5400 \mathrm{~m}$ on Lhotse Shar Glacier. $T_{d}$ was measured at four sites located about $1 \mathrm{~km}$ upglacier from the lake-calving terminus at 5045-5055 $\mathrm{m}$ (Fig. 2). Debris thicknesses were $1.5 \mathrm{~m}$ (IM4), $0.45 \mathrm{~m}$ (IM11), $0.33 \mathrm{~m}$ (IM13) and $0.26 \mathrm{~m}$ (IM14). 
The Cryosphere Discuss., https://doi.org/10.5194/tc-2017-239

Manuscript under review for journal The Cryosphere

Discussion started: 30 November 2017

(c) Author(s) 2017. CC BY 4.0 License.

made in 2014 for three sites indicated ablation of $0.85 \mathrm{~m}$ at IM13 and greater than $1.0 \mathrm{~m}$ at IM11 and IM14 (Rounce et al., 2015).

\subsection{Ablation calculations}

Three different methods for calculating ablation beneath supraglacial debris are compared using the data collected at Khumbu, Ngozumpa and Imja-Lhotse Shar Glaciers.

\subsubsection{Degree Day Factors}

Ablation was calculated using DDFs derived from a previous study of Khumbu Glacier (Fig. 3; Kayastha et al., 2000). We fitted a power-law function to the five available data points spanning debris thickness $\left(h_{d}\right)$ from $0.05 \mathrm{~m}$ to $0.4 \mathrm{~m}$ and extrapolated this relationship to derive:

$\mathrm{DDF}=3.4554 * h_{d}{ }^{-0.577}$

265

Using Equation 1 and assuming that similarities in debris characteristics will give similar results for these three Everest region glaciers, DDFs for the $h_{d}$ represented here $(0.26-2.0 \mathrm{~m})$ range from $7.52 \mathrm{~mm}$ w.e. ${ }^{\circ} \mathrm{C}^{-1}$ day $^{-1}$ to $2.32 \mathrm{~mm}$ w.e. ${ }^{\circ} \mathrm{C}^{-1} \mathrm{day}^{-1}$. The number of positive degree days used to calculate total ablation by multiplication with the DDF was summed from the positive mean daily $T_{a}$ during the monsoon season for each site.

\subsubsection{Downward heat flux}

Ablation can be calculated from the heat flux through supraglacial debris to the underlying ice as:

$M=Q_{m} / \rho * L_{f}$

where $M$ is surface lowering in $\mathrm{m} \mathrm{s}^{-1}$ and equal to ablation assuming that the emergence velocity is zero (i.e. for stagnant ice, as has been established for our study sites by Quincey et al., 2009), $Q_{m}$ is downward energy flux delivered to the underlying ice in $\mathrm{W} \mathrm{m}^{-2}, \rho$ is the density of ice and $L_{f}$ is the latent heat of fusion (334 kJ kg$)^{-1}$ ). The energy flux, $Q_{m}$, is approximated by the effective conductive heat flux through the overlying debris, which is controlled by the temperature gradient through the debris layer $\left(\delta T_{d} / \delta h_{d}\right)$ and the effective thermal conductivity $(k)$. A useful simplification is to assume that $\delta T_{d} / \delta h_{d}$ is linear. While this is not generally the case instantaneously (e.g. Rounce et al., 2015) this is suggested to be true on daily or longer intervals (Nicholson and Benn, 2006). $Q_{m}$ can therefore be stated as:

$Q_{m}=Q_{c}=-k *\left(T_{s, \text { mean }}-T_{i, \text { mean }}\right) / h_{d}$ 
The Cryosphere Discuss., https://doi.org/10.5194/tc-2017-239

Manuscript under review for journal The Cryosphere

Discussion started: 30 November 2017

(c) Author(s) 2017. CC BY 4.0 License.

where $Q_{c}$ is the conductive heat flux, and $T_{\text {mean }}$ are daily mean values. $k$ can be estimated by comparing the result of this calculation with ablation measured using a stake, or calculated if the effective thermal diffusivity, density, water content and specific heat capacity of the debris layer are known or estimated. Published values of $k$ for supraglacial debris measured on glaciers in Nepal and Europe are in the range $0.5-1.8 \mathrm{~W} \mathrm{~m}^{-1}{ }^{\circ} \mathrm{C}^{-1}$ (Table 2). These values are sensitive to debris water content; $k$ can be $2-3$ times greater for saturated debris than dry debris (Nicholson and Benn, 2006).

Here, $k$ was computed following the method of Conway and Rasmussen (2000): Temperatures were resampled to hourly increments, and apparent thermal diffusivity was taken as the linear fit between the derivative of temperature plotted against the second derivative of temperature with depth. Apparent thermal diffusivity was determined for; (a) the bulk layer using data from all levels of the debris cover simultaneously, and (b) each level individually. Visual inspection of plots allowed assessment of the presence of non-conductive processes (e.g. convective or latent heat exchange) within the debris profile. On this basis, the site with the least evidence of non-conductive processes was selected from each glacier and thermal conductivity was computed from the bulk apparent thermal diffusivity for the summer months of July and August. This two-month measurement period was deemed to be representative of the core ablation season and was used because these months show stable $T_{d}$ above $0^{\circ} \mathrm{C}$, and is therefore not affected by seasonal temperature or water phase change, that have been shown to affect $k$ (Nicholson and Benn, 2013). $k$ was calculated from the apparent thermal diffusivity using the same values for the density of rock $\left(2700 \mathrm{~kg} \mathrm{~m}^{-3}\right)$, volumetric heat capacity of rock $\left(750 \mathrm{~J} \mathrm{~kg}^{-1}{ }^{\circ} \mathrm{C}^{-1} \pm\right.$ $10 \%$ ), and effective porosity (0.33) as in previous studies in the region (Conway and Rasmussen, 2000; Nicholson and Benn, 2013; Rounce et al., 2015). A conservative error on the volumetric heat capacity of $10 \%$ was assumed in line with previous studies (e.g. Conway and Rasmussen, 2000). Few data are available with which to quantify the uncertainties in the calculation of $k$ using the method described here, and we consider this value to be representative based on the range of possible values tested by Nicholson (2005). Error in the calculated apparent thermal diffusivity are included in the total error. $M$ was calculated using daily mean $T_{s}$ and assuming that $T_{i}$ was zero. If $\delta T_{d} / \delta h_{d}$ was negative then ablation was assumed to be zero.

\subsubsection{Thermal diffusion model}

We used a point-based surface energy balance and thermal diffusion model of supraglacial debris to estimate the flux of heat through the debris layer and ablation at the ice surface. The numerical model is described by Collier et al. (2014; 2015). For this study, the model configuration and debris physical properties were specified following Collier et al. (2015) and Nicholson and Benn (2013). The vertical debris column was resolved into $0.01 \mathrm{~m}$ layers and porosity decreased linearly from $40 \%$ to $20 \%$ with 
The Cryosphere Discuss., https://doi.org/10.5194/tc-2017-239

Manuscript under review for journal The Cryosphere

Discussion started: 30 November 2017

(c) Author(s) 2017. CC BY 4.0 License.

depth. The properties of each layer were computed as weighted functions of representative whole-rock values and the contents of the pore space (air, water, ice), such that a whole-rock value for $k$ of $2.5 \mathrm{~W}$ $\mathrm{m}^{-1}{ }^{\circ} \mathrm{C}^{-1}$ would give bulk $k$ values through the debris column between $1.5 \mathrm{~W} \mathrm{~m}^{-1}{ }^{\circ} \mathrm{C}^{-1}$ and $2.0 \mathrm{~W} \mathrm{~m}^{-1}{ }^{\circ} \mathrm{C}^{-}$

${ }^{1}$. The model was run in a simplified form wherein $T_{s}$ was specified from observations collected every 30 minutes during the 131-day monsoon season (3 June to 11 October). As a result, the surface energy balance terms as well as snow variables were not simulated. For dry debris simulations, the model was therefore essentially reduced to a diffusion model in the glacier column down to a total depth of $10 \mathrm{~m}$, with a grid spacing of $0.01 \mathrm{~m}$ in the debris followed by variables levels in the underlying ice, ranging in thickness from $0.01 \mathrm{~m}$ near the debris-ice interface down to $2 \mathrm{~m}$ near the base of the ice column. For moist simulations, instantaneous infiltration of moisture from precipitation measured at the Pyramid Observatory (Fig. 4; assumed to be liquid and provide zero heat flux to the debris) was also considered, with phase changes simulated depending on the simulated $T_{d}$. Since the surface energy balance was not simulated and near-surface vapour pressures were unavailable, vapour fluxes in the debris were set to zero. The air density in the debris pore space was specified from a standard atmosphere at $5000 \mathrm{~m}$.

Using this simplified model, three experiments were performed:

1. To compare simulated ablation rates between sites using standardised debris properties. The model was forced with 30-minute $T_{s}$ from four sites; KH1 $\left(h_{d}=0.9 \mathrm{~m}\right), \mathrm{KH} 2(0.6 \mathrm{~m})$; KH4 $(0.2$ $\mathrm{m})$, and NG1 $(0.65 \mathrm{~m})$. The debris was treated as dry and precipitation was considered to be zero. $k$ was computed from the whole-rock value of $2.5 \mathrm{~W} \mathrm{~m}^{-1}{ }^{\circ} \mathrm{C}^{-1}$ used Collier et al. (2015).

2. To apply field-measured bulk effective $k$ values to allow comparison with the downward heat flux method. These simulations were identical to those in Experiment 1 except that this used glacier-specific $k$ values of $0.977 \mathrm{~W} \mathrm{~m}^{-1}{ }^{\circ} \mathrm{C}^{-1}$ (KH1) and $1.432 \mathrm{~W} \mathrm{~m}^{-1}{ }^{\circ} \mathrm{C}^{-1}$ (NG1).

3. To assess the impact of a moist debris layer compared to Experiment 1. The model simulated dry and moist debris at KH1 for summer 2015, KH2 for summer 2014; and KH4 for summer 2014. These simulations were forced by $T_{s}$ resampled to 60-minute intervals to correspond to the 60-minute precipitation measurements from the Pyramid Observatory.

The debris depths used in these experiments refer to the thickness overlying the deepest thermistor in the debris layer, which corresponds to the thickness down to the debris-ice interface at all sites except NG1 and KH1. Therefore, at these two sites we expected that the model would simulate overly cold basal debris temperatures. As $T_{s}$ was not available at $\mathrm{KH} 2$ for summer 2014, simulations for this period were forced with $T_{s}$ from $\mathrm{KH} 1$ over the same period.

\section{Results}

Air $\left(T_{a}\right)$ and near-surface $\left(T_{s}\right)$ and debris temperature $\left(T_{d}\right)$ measurements from five sites on Khumbu Glacier are presented here. Some of these timeseries are incomplete, as data collection at several sites 
The Cryosphere Discuss., https://doi.org/10.5194/tc-2017-239

Manuscript under review for journal The Cryosphere

Discussion started: 30 November 2017

(c) Author(s) 2017. CC BY 4.0 License.

360 was affected by movement of the glacier surface due to debris slumping or ice collapse during the ablation season. At $\mathrm{KH} 2$, although a thermistor was placed at the debris-ice interface at the start of the measurement period in 2014 and the site remained intact, ablation of the underlying ice caused the thermistor to migrate with the base of the debris resulting in positive $T_{i}$ (Fig. 4); these observations are discussed in Section 6.1. At KH3, the glacier surface collapsed in early June 2014 and exhumed the sensors so $T_{s}$ and $T_{d}$ measurements after the start of the monsoon are considered unreliable and only $T_{a}$ is used for analysis. All $p<0.05$.

\subsection{Timing and character of the monsoon}

Meteorological observations made between 1994 and 2011 indicate that the monsoon season in the upper Khumbu valley is characterised by cumulative precipitation amounts between $382 \mathrm{~mm}$ and 442 $\mathrm{mm}$ (Bollasina et al., 2002). The timing of the monsoon season at Khumbu Glacier in 2014 was similar to previous years, as indicated by precipitation and $T_{a}$ measurements made at the Pyramid Observatory and our on-glacier data (Fig. 4). We therefore consider the monsoon season as the 131-day period between 3 June and 11 October when mean daily $T_{a}$ were consistently above $0^{\circ} \mathrm{C}$ and some precipitation occurred on most days (122 out of 131 days) with values up to $21.4 \mathrm{~mm} \mathrm{day}^{-1}$ and a mean daily value of $3.1 \pm 4.1 \mathrm{~mm} \mathrm{day}^{-1}$. During the monsoon season, mean daily $T_{a}$ initially rose to give several days with particularly high values in mid-August then remained high until the last week of September (Fig. 4). The majority of precipitation occurred during July and August. We sub-divided the monsoon season into early, middle and late stages on the basis of these observations of $T_{a}$ and precipitation (Table 3).

We observed a storm that deposited decimetres of snow over several days at the end of May (Fig. 4) recorded by precipitation measurements of up to $26.5 \mathrm{~mm} \mathrm{day}^{-1}$ (mean of $7.7 \pm 10.5 \mathrm{~mm} \mathrm{day}^{-1}$ ) at the Pyramid Observatory (Fig. 4). A similar snowstorm occurred during mid-October as a result of Cyclone Hudhud, which reached Nepal on 14 October 2014 and resulted in a marked drop in $T_{a}$ and increased precipitation (Shea et al., 2015). At Khumbu Glacier in mid-October, precipitation was up to $27.9 \mathrm{~mm}$ day $^{-1}$ with a mean of $4.9 \pm 9.0 \mathrm{~mm} \mathrm{day}^{-1}$. During both snowstorms, mean daily $T_{a}$ was close to or below $0^{\circ} \mathrm{C}$ and precipitation amounts were greater than $20 \mathrm{~mm} \mathrm{day}^{-1} . T_{s}$ and $T_{d}$ were depressed below $0{ }^{\circ} \mathrm{C}$ (Fig. 4e-h) with no detectable diurnal signal despite warm daytime $T_{a}$ (Fig. 5). We consider these snowstorms to comprise part of the pre-monsoon (25 May to 2 June) and post-monsoon (12 October to 19 October) seasons, in line with similar transitional periods recorded in previous years at the Pyramid Observatory (Bonasoni et al., 2010). Similar events were observed at Imja-Lhotse Shar Glacier in 2014, where the debris was assumed to be snow-covered and ablation assumed to be zero during 26 May-1 June and 13-20 October (Rounce et al., 2015). 
The Cryosphere Discuss., https://doi.org/10.5194/tc-2017-239

Manuscript under review for journal The Cryosphere

Discussion started: 30 November 2017

(c) Author(s) 2017. CC BY 4.0 License.

\subsection{Air temperatures $\left(T_{a}\right)$}

During the monsoon season, minimum mean daily $T_{a}$ across Khumbu Glacier was $-2.0^{\circ} \mathrm{C}$ on the last day of the monsoon season (12 October 2014) at $\mathrm{KH} 4$, and maximum daily mean $T_{a}$ was $13.0^{\circ} \mathrm{C}$ on 5 August at $\mathrm{KH} 2$ (Fig. 5). Seasonal mean $T_{a}$ ranged from $5.5 \pm 2.4^{\circ} \mathrm{C}$ at $\mathrm{KH} 2$ to $3.9 \pm 2.1^{\circ} \mathrm{C}$ at $\mathrm{KH} 4 . T_{a}$ rose from a daily mean of around $0^{\circ} \mathrm{C}$ during the pre-monsoon to around $4{ }^{\circ} \mathrm{C}$ over four days at the start of the early monsoon, and the debris profiles started to warm rapidly three days after $T_{a}$ increased (Fig. 4). Maximum $T_{a}$ was reached by 7 August, and for this week (7-14 August) maximum daily $T_{a}$ were between $5.8 \pm 0.9^{\circ} \mathrm{C}$ at $\mathrm{KH} 4$ and $8.1 \pm 1.8^{\circ} \mathrm{C}$ at $\mathrm{KH} 2$. The mean diurnal $T_{a}$ range varied between $11.3 \pm$ $3.2^{\circ} \mathrm{C}$ at $\mathrm{KH} 2$ and $14.1 \pm 3.6^{\circ} \mathrm{C}$ at $\mathrm{KH} 4$, and showed cycles of between four and seven days when the diurnal $T_{a}$ range decreased across all four sites simultaneously (Fig. 6). During the late monsoon, $T_{a}$ declined at a similar rate at all sites from $3-5^{\circ} \mathrm{C}$ and remained close to $0^{\circ} \mathrm{C} . T_{a}$ were compared with each other and with measurements made at the Pyramid Observatory 50 m higher than KH1-3, and 130 $\mathrm{m}$ lower than KH4. There was a good correlation between $T_{a}$ at $\mathrm{KH} 2$ and $\mathrm{KH} 4$ through the pre-monsoon and early monsoon $\left(r^{2}=0.95\right.$ and 0.94$)$, which weakened after 15 July when $T_{a}$ at $\mathrm{KH} 2$ rose earlier in the day than at $\mathrm{KH} 4$, leading by 3.5 hours and 5 hours in the middle and late monsoon.

\subsection{Near-surface debris temperatures $\left(T_{s}\right)$}

Daily mean $T_{s}$ through the 2014 monsoon season at $\mathrm{KH} 2$ was $7.0 \pm 2.0^{\circ} \mathrm{C}$ and at $\mathrm{KH} 4$ was $6.6 \pm 2.1^{\circ} \mathrm{C}$ (Table 4). For comparison, daily mean $T_{s}$ through the 2015 monsoon season at $\mathrm{KH} 1$ was $9.7 \pm 2.3^{\circ} \mathrm{C}$ assuming the same duration as in 2014. $T_{s}$ rose more rapidly than $T_{a}$ in the morning and remained higher as $T_{a}$ fell in the afternoon (Fig. 7). The mean diurnal range of $T_{s}$ was greater than that of $T_{a} ; 21.2$ $\pm 5.9^{\circ} \mathrm{C}$ for $T_{s}$ compared to $11.3 \pm 3.2^{\circ} \mathrm{C}$ for $T_{a}$ at $\mathrm{KH} 2$, and $22.1 \pm 4.0^{\circ} \mathrm{C}$ for $T_{s}$ compared to $14.1 \pm$ $3.6^{\circ} \mathrm{C}$ for the $T_{a}$ at $\mathrm{KH} 4$. There was a good correlation between mean daily $T_{a}$ and $T_{s}$ at $\mathrm{KH} 2$ in the early monsoon $\left(r^{2}=0.93\right)$, which weakened as the lag increased from zero in the early monsoon to four hours during the late monsoon. The lag between $T_{a}$ and $T_{s}$ depends on the transfer time to heat the air as the debris surface warms and is dependent on the rate of turbulent heat exchange, and may be shorter at $\mathrm{KH} 4$ due to less turbulence and stronger katabatic winds at this higher-elevation site. Cross-correlation of $T_{a}$ and $T_{s}$ showed that $T_{s}$ tracked $T_{a}$ most strongly during the early and late monsoon $\left(r^{2}=0.93\right.$ and $0.91)$ but that this relationship weakened during the middle monsoon $\left(r^{2}=0.54\right)$ which could be due to

425 deposition or evaporation of snow during this period. Conversely, there was a strong correlation but no lag between $T_{a}$ and $T_{s}$ at $\mathrm{KH} 4$ where the debris was thin throughout the early, middle and late monsoon $\left(r^{2}>0.96\right)$ (Fig. 7). The shorter lag between $T_{a}$ and $T_{s}$ at KH4 compared to KH2 may be due to more effective heating over thinner debris as this is generally found at higher elevations ( $c f$. Steiner and Pelliciotti, 2016).

\subsection{Debris layer temperatures ( $T_{d}$ and $T_{i}$ )}


The Cryosphere Discuss., https://doi.org/10.5194/tc-2017-239

Manuscript under review for journal The Cryosphere

Discussion started: 30 November 2017

(c) Author(s) 2017. CC BY 4.0 License.

During the pre-monsoon in 2014, mean daily $T_{d}$ at each site was close to $0^{\circ} \mathrm{C}$ throughout the vertical profiles as a result of a snowstorm. The debris profiles started to warm shortly after $T_{a}$ increased at the start of the monsoon season, with positive mean daily $T_{d}$ penetrated at least halfway through the debris thickness within five days (Fig. 4). The rapid increase in the diurnal range of $T_{s}$ one day before the end of the pre-monsoon at KH4 and a day earlier at KH2 (Fig. 5) suggests that the snowpack did not remain in place once the monsoon season started. $T_{d}$ in at least the upper half of each profile remained above $0^{\circ} \mathrm{C}$ for around 12 days after $T_{a}$ fell to $0^{\circ} \mathrm{C}$ during the late monsoon, and only cooled below $0{ }^{\circ} \mathrm{C}$ when $T_{a}$ dropped to around $-5^{\circ} \mathrm{C}$ during the post-monsoon with the arrival of a snowstorm resulting from Cyclone Hudhud. A less pronounced depression of $T_{a}$ and $T_{d}$ was observed at KH1 in 2015 and potentially 2016, and NG1 in 2002 (Fig. 4). However, the debris layer did not freeze during these periods, suggesting that the snowstorms during the pre-monsoon and post-monsoon in 2014 were exceptionally cold periods.

445 At $\mathrm{KH} 2$, mean daily $T_{i}$ was $2.3 \pm 1.3^{\circ} \mathrm{C}$ due to migration of the sensor (see Section 6.1). A lag of approximately 8-9 hours between $T_{a}$ and $T_{i}$ was observed. There was no significant correlation between $T_{a}$ and $T_{i}$ during the pre-monsoon and post-monsoon, and only weak correlation $\left(r^{2}<0.29\right)$ during the monsoon season. Cross-correlation showed a reasonable correlation between $T_{a}$ and $T_{i}$ through the early and middle monsoon $\left(r^{2}=0.50\right.$ and 0.51$)$ and a stronger relationship in the late monsoon $\left(r^{2}=0.91\right)$.

450 The relationship between $T_{a}$ and $T_{i}$ was weaker during the pre-monsoon $\left(r^{2}=0.44\right)$ and post-monsoon $\left(r^{2}=0.47\right)$. The amplitude of the diurnal $T_{i}$ cycle at $\mathrm{KH} 2$ was about $0.4^{\circ} \mathrm{C}$ until $15 \mathrm{July}$, after which the diurnal range increased at a rate of $0.7^{\circ} \mathrm{C}$ day $^{-1}$ to $6.8^{\circ} \mathrm{C}$ at the end of the monsoon season such that daily freeze-thaw cycles occurred at the debris-ice interface at this site. Daily mean $T_{i}$ reached a maximum of $5.0^{\circ} \mathrm{C}$ on 5 September, then decreased to about $1.5^{\circ} \mathrm{C}$ at the end of the monsoon season. These results suggest that the sensor at the debris-ice interface migrated and therefore we do not consider these results to represent $T_{i}$ after this occurred. At $\mathrm{KH} 4$, mean daily $T_{i}$ was $0.2 \pm 0.1^{\circ} \mathrm{C}$ and the lag between peak daily $T_{a}$ and peak daily $T_{i}$ was 2 hours in the early and middle monsoon, which increased to 4.5 hours in the late monsoon. Cross-correlation showed strong correlation between $T_{a}$ and $T_{i}$ during the early and middle monsoon at KH4 $\left(r^{2}>0.92\right)$ that weakened in the late monsoon as the diurnal $T_{a}$ signal reduced in amplitude. $T_{i}$ remained close to zero throughout the monsoon season (Fig. $7 \mathrm{~d}-\mathrm{f})$. The mean daily diurnal range of $T_{i}$ was approximately $1.0^{\circ} \mathrm{C}$ throughout the monsoon season.

\subsection{Regional comparison of $T_{d}$ profiles}

We compared the mean debris thickness-debris temperature $\left(\delta T_{d} / \delta h_{d}\right)$ profiles at KH1 (2014 and 2015), 465 KH2 (2014), KH4 (2014) and KH5 (2015) with measurements from NG1 (2001-2002) and NG2 (2014-2016) and IM4, IM11, IM13 and IM14 (all 2014) (Fig. 8). During the summer and monsoon seasons, $T_{d}$ generally decreased with increasing $h_{d}$, and the rate of $T_{d}$ decrease with depth was 
The Cryosphere Discuss., https://doi.org/10.5194/tc-2017-239

Manuscript under review for journal The Cryosphere

Discussion started: 30 November 2017

(c) Author(s) 2017. CC BY 4.0 License.

approximately linear in the upper and lower parts of the debris layer. Summer $\delta T_{d} / \delta h_{d}$ fitted into groups according to $h_{d}$ (Fig. 8a). Where debris was thick $(>0.5 \mathrm{~m})$, summer $\delta T_{d} / \delta h_{d}$ gave a mean of $-4.0^{\circ} \mathrm{C} \mathrm{m}^{-1}$.

470 Where debris was thin $(<0.5 \mathrm{~m})$, mean $T_{d}$ was generally colder and $\delta T_{d} / \delta h_{d}$ was steeper compared to the profiles through thick debris with a mean of $-18.2^{\circ} \mathrm{C} \mathrm{m}^{-1}$. $\mathrm{KH} 2\left(h_{d}=0.7 \mathrm{~m}\right)$ had a similar $\delta T_{d} / \delta h_{d}$ to the thicker debris layers but similar $T_{d}$ values to the thin debris layers. In each case, $T_{d}$ at the greatest depth measured was about $4^{\circ} \mathrm{C}$ cooler than $T_{s}$ with a slightly greater difference, of about $1^{\circ} \mathrm{C}$ through thin debris. The depth of maximum inflection in the $\delta T_{d} / \delta h_{d}$ profile varied between about $0.5 \mathrm{~m}$ for thick debris and about $0.1 \mathrm{~m}$ for thin debris. Summer $\delta T_{d} / \delta h_{d}$ were approximately linear suggesting that daily mean $T_{d}$ gives a good approximation to a linear profile (Nicholson and Benn, 2006) whereas instantaneous $T_{d}$ measurements are unlikely to do so (Rounce et al., 2015). During the pre- and postmonsoon, $\delta T_{d} / \delta h_{d}$ were close to zero as $T_{d}$ was constant through the entire thickness when the debris was snow covered.

Winter $\delta T_{d} / \delta h_{d}$ showed similar trends at both Khumbu and Ngozumpa Glaciers despite being collected during different years (Fig. 8b). Winter $\delta T_{d} / \delta h_{d}$ were steeper and had narrower ranges of $T_{d}$ than the summer profiles. Mean $T_{d}$ was $-4.9^{\circ} \mathrm{C}$ at $\mathrm{KH} 1,-3.2^{\circ} \mathrm{C}$ at $\mathrm{KH} 5,-3.0^{\circ} \mathrm{C}$ at $\mathrm{NG} 1$, and $-2.8^{\circ} \mathrm{C}$ at $\mathrm{NG} 2 . T_{d}$ throughout the debris layer at each site remained below $0^{\circ} \mathrm{C}$. Winter $\delta T_{d} / \delta h_{d}$ through these thick debris layers had a mean of $1.1^{\circ} \mathrm{C} \mathrm{m}^{-1}$ reflecting a reversal at three of the five sites compared to the summer profiles. $\mathrm{KH} 2$ showed a total decrease in $T_{d}$ of about $1{ }^{\circ} \mathrm{C}$ through the debris layer, giving a similar value at the debris-ice interface to that recorded at $\mathrm{KH} 5$. At NG2, $T_{d}$ decreased by about $0.5^{\circ} \mathrm{C}$ through the 1.8 $\mathrm{m}$ profile. At $\mathrm{NG} 1, \mathrm{KH} 1$ and $\mathrm{KH} 5, T_{d}$ increased slightly with increasing debris thickness in winter whereas an opposing trend with a similar gradient was observed at $\mathrm{KH} 2$.

At six sites (KH2, 3, 4, 5, NG2 and IM14), $T_{i}$ was measured by the lowest thermistors installed in contact with the debris-ice interface. Positive $T_{i}$ were recorded from 13 May 2014 at KH2, suggesting that ablation was already taking place before the onset of the monsoon season. The number of days for which $T_{i}$ was positive after the start of the pre-monsoon (25 May 2014) was 145 at KH2 (mean value of $2.3^{\circ} \mathrm{C}$; see Section 6.1$), 120$ at $\mathrm{KH} 4\left(0.2^{\circ} \mathrm{C}\right), 143$ at $\mathrm{NG} 2\left(1.3^{\circ} \mathrm{C}\right)$ and 153 at $\mathrm{IM} 14\left(0.2^{\circ} \mathrm{C}\right.$; where thermistors were installed from 31 May and recorded positive values so may include an additional six days of ablation). $T_{i}$ remained positive at IM14 until the end of the summer (31 October) whereas at $\mathrm{KH} 2$ and $\mathrm{KH} 4, T_{i}$ was negative by the end of the monsoon season (16 October and 3 October). The measurement record for KH5 ends on 11 May 2016 and no positive $T_{i}$ were recorded, suggesting that sustained pre-monsoon ablation only occurs from around mid-May.

\section{Estimating sub-debris ice ablation on Himalayan debris-covered glaciers 5.1 Degree Day Factors}


The Cryosphere Discuss., https://doi.org/10.5194/tc-2017-239

Manuscript under review for journal The Cryosphere

Discussion started: 30 November 2017

(c) Author(s) 2017. CC BY 4.0 License.

The total positive degree days (PDDs) were $386-524^{\circ} \mathrm{C}$ over 131 days on Khumbu Glacier in 2014 , and $436^{\circ} \mathrm{C}$ on Ngozumpa Glacier in 2002 (Table 4). $T_{a}$ was not measured by Rounce et al. (2015) at ImjaLhotse Shar Glacier so the authors used measurements made at the Pyramid Observatory which they adjusted using a lapse rate of $-6.5^{\circ} \mathrm{C} \mathrm{km}^{-1}$ to account for the $15 \mathrm{~m}$ higher altitude of the surface of their site compared to the Pyramid $T_{a}$ sensor. There are gaps in these $T_{a}$ measurements totaling 21 days during the monsoon season (Fig. 4). Gaps were filled using the daily mean $T_{a}$ at the Pyramid during the monsoon season $\left(2.1^{\circ} \mathrm{C}\right)$ to give $303^{\circ} \mathrm{C}$ over 131 days, which scaled to $291^{\circ} \mathrm{C}$ to the sites at $5050 \mathrm{~m}$ on Imja-Lhotse Shar Glacier. Estimated total ablation ranged from $0.80 \mathrm{~m}$ w.e. at IM4 beneath $1.5 \mathrm{~m}$ of debris to $2.67 \mathrm{~m}$ w.e. at KH4 beneath $0.30 \mathrm{~m}$ of debris, and decreased with increasing debris thickness. Estimated ablation at IM13 was more than double the amount indicated by the stake measurements (1.91 m w.e. compared to $0.85 \mathrm{~m}$ w.e.). Where stakes indicated ablation greater than $1 \mathrm{~m}$, calculated ablation was $1.59 \mathrm{~m}$ w.e. at IM11 and $2.19 \mathrm{~m}$ w.e. at IM14.

\subsection{Downward heat flux}

Estimating effective thermal conductivity $(k)$ relies on assuming that the thermal properties of the debris are relatively constant in space. However, the 60-minute thermal profiles used to calculate $k$ showed greater between-site variation than expected, likely as a result of non-conductive processes, rapidly changing temperatures, strong stratifications or some combination of these factors. Therefore, for each glacier, the site with the most linear $T_{d}$ profiles and the least scatter around the best fit to apparent thermal diffusivity was used to calculate $k$, assuming that this single value is representative at the glacier scale; a realistic assumption if the debris lithology and moisture content are consistent within glaciers. Calculated $k$ was $0.98 \pm 0.10 \mathrm{~W} \mathrm{~m}^{-1}{ }^{\circ} \mathrm{C}^{-1}$ for $\mathrm{KH} 1,1.43 \pm 0.14 \mathrm{~W} \mathrm{~m}^{-1}{ }^{\circ} \mathrm{C}^{-1}$ for $\mathrm{NG} 1$, and $1.98 \pm$ $0.20 \mathrm{~W} \mathrm{~m}^{-1}{ }^{\circ} \mathrm{C}^{-1}$ for IM4. Calculated surface lowering $(M)$ using these glacier-specific values for $k$ ranged from $0.18 \mathrm{~m}$ w.e. at $\mathrm{KH} 1$ beneath $1.5 \mathrm{~m}$ of debris to $1.84 \mathrm{~m}$ w.e. at IM14 beneath $0.26 \mathrm{~m}$ of debris. Where the depth of the debris-ice interface was known, these values for $M$ would give DDFs of $2.2 \mathrm{~mm}$ w.e. ${ }^{\circ} \mathrm{C}^{-1}$ day $^{-1}$ at $\mathrm{KH} 4$ beneath $0.3 \mathrm{~m}$ of debris, $5.8 \mathrm{~mm}$ w.e. ${ }^{\circ} \mathrm{C}^{-1}$ day $^{-1}$ at IM13 beneath $0.35 \mathrm{~m}$

530 of debris, $0.8 \mathrm{~mm}$ w.e. ${ }^{\circ} \mathrm{C}^{-1} \mathrm{day}^{-1}$ at $\mathrm{KH} 2$ beneath $0.7 \mathrm{~m}$ of debris, and $1.6 \mathrm{~mm}$ w.e. ${ }^{\circ} \mathrm{C}^{-1}$ day $^{-1}$ at $\mathrm{NG}_{2}$ beneath $1.8 \mathrm{~m}$ debris. The higher DDF for Imja-Lhotse Shar Glacier results from the local value for $k$, which was approximately double that for Khumbu Glacier $\left(1.98 \mathrm{~W} \mathrm{~m}^{-1}{ }^{\circ} \mathrm{C}^{-1}\right.$ compared to $0.98 \mathrm{~W} \mathrm{~m}^{-1}$ $\left.{ }^{\circ} \mathrm{C}^{-1}\right)$.

\subsection{Thermal diffusion model}

In Experiment 1, where the debris was treated as dry and precipitation input was zero, the model reproduced observed $T_{d}$ at each site, including the pre-monsoon and post-monsoon at $\mathrm{KH} 2$ and $\mathrm{KH} 4$ in 2014 (Fig. 9). Simulated $\delta T_{d} / \delta h_{d}$ were steeper than the observed values at NG1 and KH1 where debris thicknesses were too great to instrument down to the debris-ice interface (Fig. 10) likely because the 
The Cryosphere Discuss., https://doi.org/10.5194/tc-2017-239

Manuscript under review for journal The Cryosphere

Discussion started: 30 November 2017

(c) Author(s) 2017. CC BY 4.0 License.

540 model assumed that ice was present at the location of the lowest thermistor. Observed mean $T_{d}$ were instead about $5^{\circ} \mathrm{C}$ at the base of $\mathrm{KH} 1$ in 2014 and NG1, and about $7^{\circ} \mathrm{C}$ at the base of $\mathrm{KH} 1$ in 2015 (Fig. 10). As a result of this assumption these simulations will slightly underestimate ablation. Winter $\delta T_{d} / \delta h_{d}$ calculated for all sites closely matched observed values (not shown) and included the reversed gradient at KH2 (cf. Fig. 8b). Total melt was similar at KH1 and KH2 where debris thickness was $1.5 \mathrm{~m}(0.38$ and $0.39 \mathrm{~m}$ w.e.) and greater at KH4 where debris thickness was $0.3 \mathrm{~m}$ (1.04 m w.e.) (Table 5).

In Experiment 2, using glacier-specific bulk $k$ values calculated for $\mathrm{KH} 1$ in $2015\left(0.977 \mathrm{~W} \mathrm{~m}^{-1}{ }^{\circ} \mathrm{C}^{-1}\right)$ and NG1 (1.432 $\left.\mathrm{W} \mathrm{m}^{-1}{ }^{\circ} \mathrm{C}^{-1}\right)$ instead of the whole-rock $k$ value from Collier et al. (2015) of $2.5 \mathrm{~W} \mathrm{~m}^{-1}$ ${ }^{\circ} \mathrm{C}^{-1}$ made little difference to simulated summer $\delta T_{d} / \delta h_{d}$ (Fig. 10) but decreased the calculated monsoon season ablation from $0.38 \mathrm{~m}$ w.e. to $0.10 \mathrm{~m}$ w.e. (to $26 \%$ ) at $\mathrm{KH} 1$, and from $0.63 \mathrm{~m}$ w.e. to $0.33 \mathrm{~m}$ w.e. (to 52\%) at NG1 compared to Experiment 1 (Table 5). The downward heat flux method using the same $k$ values gave ablation of $0.18 \mathrm{~m}$ w.e. at $\mathrm{KH} 1$ and $0.23 \mathrm{~m}$ w.e. at NG1 (Table 4), which are similar to those simulated here.

In Experiment 3, the model simulated $T_{d}$ and ablation at KH1 (in 2014 and 2015), KH2 (2014) and KH4 (2014) as in Experiment 1, except that moisture in the debris layer was included and compared with equivalent dry debris layers. The moist debris layers were $0.2-0.5^{\circ} \mathrm{C}$ warmer than the dry debris during the pre- and post-monsoon (Fig. 9) due to refreezing of infiltrated precipitation within the debris layer. This difference is particularly apparent in 2014 due to high precipitation during the aforementioned snowstorms that we assume was liquid ( $c f$. Section 3.4.3). The moist debris was then $0.1-0.6^{\circ} \mathrm{C}$ cooler than the dry debris at the start of the monsoon season for about a month in 2014 and about a week in 2015 (Fig. 9) as the accumulated ice within the debris layer melted. As a result, ablation calculated beneath moist debris was less than half the amount compared to dry debris; $0.10 \mathrm{~m}$ w.e. in 2014 and $0.13 \mathrm{~m}$ w.e. in 2015 at $\mathrm{KH} 1$ (27\% and $33 \%$ of the 2015 dry debris value), $0.15 \mathrm{~m}$ w.e. at KH2 (37\%) and $0.47 \mathrm{~m}$ w.e. at KH4 (46\%) (Table 5 and Fig. 10).

\section{Discussion}

\subsection{Temperature measurements at Khumbu Glacier}

Off-glacier $T_{a}$ were $1.8-3.0^{\circ} \mathrm{C}$ cooler than those measured on-glacier (Fig. 4) due to the naturally ventilated radiation shields used to measure on-glacier $T_{a}$ and radiative and sensible heating of the surface air from the underlying warm debris, and the relatively lower position of the thermistors (1 m above the glacier surface compared to $2 \mathrm{~m}$ at the Pyramid Observatory); $r^{2}$ between the on-glacier and off-glacier $T_{a}$, excluding the intervals where data were not recorded at the Pyramid, were 0.79 for KH1, 0.53 for $\mathrm{KH} 2,0.78$ for $\mathrm{KH} 3$ and 0.78 for $\mathrm{KH} 4$. $T_{a}$ measurements were made $1 \mathrm{~m}$ above the debris surface on Khumbu Glacier, $1.5 \mathrm{~m}$ above the debris surface of Ngozumpa Glacier, and $2 \mathrm{~m}$ above the 
The Cryosphere Discuss., https://doi.org/10.5194/tc-2017-239

Manuscript under review for journal The Cryosphere

Discussion started: 30 November 2017

(c) Author(s) 2017. CC BY 4.0 License.

land surface at the Pyramid Observatory, which will influence the calculation of PDDs for each site, as will the choice of lapse rate used to extrapolate the measurements from the Pyramid Observatory to Imja-Lhotse Shar Glacier. The DDFs calculated by Kayastha et al. (2000) used $T_{a}$ measured at $1.52 \mathrm{~m}$ above the debris surface; a similar height to measurements at Ngozumpa Glacier.

Thermistors measuring $T_{s}$ need to be installed at the debris surface but shielded from direct solar radiation. We therefore installed these thermistors beneath a thin layer of debris and measured nearsurface rather than at surface temperature (Gibson et al. 2017). Movement of the glacier surface and intense precipitation during the ablation season are likely to modify this by covering or uncovering sensors entirely. This effect on measured $T_{s}$ and $T_{d}$ can be observed at KH3 where the surface collapsed during June 2014 and left sensors exposed at the ice and debris surface (Fig. 4). We observed little change in debris temperature during winter (1 November to 30 April) but during summer (1 May to 31 October) thin debris layers $(<0.5 \mathrm{~m})$ transferred heat more rapidly to the underlying ice than thick debris layers. The start and end of the 2014 monsoon season were marked by large snowstorms, which deposited decimetres of snow across these glaciers and caused the debris layer to freeze. Between these periods, the majority of thermal transfer occurred as debris layers warmed during the 131-day monsoon season.

Thermistors were present at the debris-ice interface at four sites (KH2, 4, 5 and IM14) and showed a more subdued diurnal cycle than $T_{a}$ and $T_{s}$ (Fig. 6). Mean $T_{i}$ was within measurement uncertainty of $0^{\circ} \mathrm{C}$ at $\mathrm{KH} 4\left(0 \pm 0.2^{\circ} \mathrm{C}\right)$, however it was warmer than expected at $\mathrm{KH} 2$, with a mean of $2.3 \pm 1.3^{\circ} \mathrm{C}$ and a maximum of $5.0^{\circ} \mathrm{C}$ reached on 27 September 2014. The high $T_{i}$ values recorded at $\mathrm{KH} 2$ are unexpected, as the thermistor was emplaced in the debris at the level of the ice surface, implying a maximum $T_{i}$ value of $0^{\circ} \mathrm{C}$. Possible explanations for the $T_{i}$ sensor recording positive values is that uneven ice surface or melt-out of debris from the underlying ice could mean that ablation could shift the debris-ice interface below the sensor or that warm meltwater may be present at the interface. If ablation is recalculated at $\mathrm{KH} 2$ using the heat flux method with measured $T_{i}$ rather than assuming that $T_{i}$ is $0^{\circ} \mathrm{C}$, then the $T_{d}$ gradient was shallower than implied by measurements made at the lowest sensor and total seasonal ablation was reduced from $369 \mathrm{~mm}$ w.e. to $279 \mathrm{~mm}$ w.e..

\subsection{Ablation outside the monsoon season}

The majority of ablation from glaciers in the Central Himalaya takes place during the monsoon season when air temperatures are high (Benn and Lehmkuhl, 2000). As the observational data and numerical modeling results indicate that the debris layers were frozen during the pre-monsoon and post-monsoon periods in 2014 (Fig. 4), we assumed that ablation during the monsoon season represented total annual ablation beneath debris layers with thicknesses equivalent to or greater than those measured here $(0.3$ 
The Cryosphere Discuss., https://doi.org/10.5194/tc-2017-239

Manuscript under review for journal The Cryosphere

Discussion started: 30 November 2017

(c) Author(s) 2017. CC BY 4.0 License.

m). However, $T_{d}$ was above $0^{\circ} \mathrm{C}$ during March-May at KH1 and NG1 suggesting that the ablation season may precede the start of the monsoon season by several months. Our data reliably cover the monsoon season and are less continuous outside of this period. However, $\delta T_{d} / \delta h_{d}$ have a similar form between the summer and the monsoon season, although the monsoon season profiles are uniformly 1$2^{\circ} \mathrm{C}$ warmer for thick debris layers indicating that most ablation occurs during the monsoon season (Fig. 8). These results suggest that although the thermal properties of the debris vary over time, they can be reliably approximated using seasonal mean values for a representative period. However, the impact of snowstorms such as those observed in 2014 and different meteorological conditions outside of the monsoon season likely require more detailed consideration than was possible given the available data. As a result, the values for ablation during the monsoon season presented here probably represent most, but not all, of the annual mass lost from these glaciers.

\subsection{Ablation calculations}

\subsubsection{Summary of results}

We applied three commonly used methods for calculating ablation beneath supraglacial debris using $T_{a}$, $T_{s}$ and $T_{d}$ measured through the 131-day monsoon season at 11 sites on three debris-covered glaciers in the Everest region. All values are given in water equivalent (w.e.) using a density of ice of $900 \mathrm{~kg} \mathrm{~m}^{-3}$. Each method gave different estimates of total seasonal ablation, although all methods indicated decreasing ablation with increasing debris thickness (Fig. 11). Debris thicknesses between sites ranged from $0.26 \mathrm{~m}$ to about $2.0 \mathrm{~m}$, although not all sites were considered using each method. DDFs driven by $T_{a}$ gave the greatest estimates of ablation across all sites, ranging from $0.68 \mathrm{~m}$ w.e. at IM4 beneath 1.5 $\mathrm{m}$ of debris to $2.67 \mathrm{~m}$ w.e at KH4 beneath $0.3 \mathrm{~m}$ debris. Downward heat flux driven by $T_{s}$ gave slightly lower estimates of ablation ranging from $0.18 \mathrm{~m}$ w.e at $\mathrm{KH} 1$ beneath $1.5 \mathrm{~m}$ debris to $1.84 \mathrm{~m}$ w.e at IM14 beneath $0.26 \mathrm{~m}$ debris. The thermal diffusion model ranged from $0.10-0.47 \mathrm{~m}$ w.e. for moist debris layers with thicknesses of 1.5-0.3 m, whereas those calculated using downward heat flux were 0.18-0.83 m w.e. for the same debris thicknesses. We used our estimates of ablation to derive an Østrem curve specifically for monsoon-influenced glaciers in the Himalaya. This relationship between debris thickness and ablation can be most simply approximated similar to the approach of Carenzo et al. (2016) using a power-law function; $M=a * d_{h}^{\wedge} b$ where $a$ and $b$ are constants. If we exclude the DDF results, then $a$ is around 300 and $b$ around -1 (Fig. 11). As only three ablation stake measurements from Imja-Lhotse Shar Glacier were available to compare with these calculations we are unable to demonstrate that one method is more accurate than another. Instead we discuss the value and limitations of each set of results. 
The Cryosphere Discuss., https://doi.org/10.5194/tc-2017-239

Manuscript under review for journal The Cryosphere

Discussion started: 30 November 2017

(c) Author(s) 2017. CC BY 4.0 License.

The relationship between DDFs and debris thickness (Fig. 3) was defined by fitting a power-law function $\left(r^{2}=0.94\right)$ to the measurements of ablation beneath debris-covered ice collected at Khumbu Glacier by Kayastha et al. (2000). The DDFs calculated by Kayastha et al. (2000) are likely to overestimate ablation compared to calculations that take into account the energy balance of the debris layer. The use of a DDF approach relies on the accurate measurement of $T_{a}$ and ablation when the DDFs were calculated, and that the site studied and the measurement period are representative of the glacier through its ablation season. This is particularly challenging for debris-covered glaciers where ablation is highly spatially variable (Benn et al., 2012). Kayastha et al. (2000) measured $T_{a}$ and ablation over 10 days in May/June 1999 close to Everest Base Camp at 5350 m on Khumbu Glacier. The applicability of these DDFs depends on how representative the measurements are of conditions over the whole monsoon season, and also how appropriate it is to extrapolate DDFs for debris thicknesses of $0.05-0.4 \mathrm{~m}$ to a wider range of values. These short-term measurements made during the pre-monsoon season when the debris was dry are likely to overestimate ablation compared to a debris layer with a representative moisture content. A further limitation is that the DDFs was derived for artificially prepared debris plots that were small in area and therefore likely to experience differential ablation at their margins and development of surface relief. The exclusion of surface topography would remove the effects of solar radiation balance, lateral energy transfer and modification of debris thickness at the margins of each plot.

\subsubsection{Limitations of calculations using downward heat flux}

Ablation stake measurements are available for three sites on Imja-Lhotse Shar Glacier where debris was $0.26 \mathrm{~m}, 0.33 \mathrm{~m}$ and $0.45 \mathrm{~m}$ thick, with a mean of $0.35 \mathrm{~m}$. Two stakes only give minimum values as they completely melted out of the ice during the monsoon (Rounce et al. 2015). At IM11 and IM14, the 1-m long stakes completely melted out of the ice indicating ablation of at least $1 \mathrm{~m}$. At IM13, ablation was $0.85 \mathrm{~m}$ over a period of 175 days that included the monsoon season (18 May to 9 November 2014) equivalent to $5.7 \mathrm{~mm}$ w.e. day ${ }^{-1}$ and $4.9 \mathrm{~mm}^{2}$ w.e. day ${ }^{-1}$. For the 131-day period that we used to represent the monsoon, this would give total ablation of $0.75 \mathrm{~m}$ w.e. at IM11 and IM14, and $0.64 \mathrm{~m}$ w.e. at IM13. The results from the DDF and downward heat flux calculations give values 2-3 times greater than these measurements (Table 4). However, we note that Rounce et al. (2015) found a much lower thermal conductivity at IM13, which would reduce the overestimate in modelled melt at this site, because their $k$ values were calculated over a longer period ( 2 June to 12 October) than that used here ( 1 June to 31 July). The difference between these results indicates that the apparent thermal diffusivity of the debris varies substantially during the summer, for example due to phase changes at the start and end of the monsoon season. Based on the similarities between the sites in terms of climate, altitude, debris lithology and grain size discussed above, we would expect $k$ values to be similar for each site and glacier over the same period of time. This method is dependent on $T_{s}$ and the differences in $k$ between 
The Cryosphere Discuss., https://doi.org/10.5194/tc-2017-239

Manuscript under review for journal The Cryosphere

Discussion started: 30 November 2017

(c) Author(s) 2017. CC BY 4.0 License.

glaciers result from these measurements. Therefore we used a generic whole-rock $k$ of $2.5 \mathrm{~W} \mathrm{~m}^{-1}{ }^{\circ} \mathrm{C}^{-1}$ in Experiments 1 and 3 with the thermal diffusion model to avoid compounding the effect of the $T_{s}$ measurements on calculated ablation.

\subsubsection{Limitations of the thermal diffusion model}

The thermal diffusion model driven by $T_{s}, T_{d}$ and properties of the debris layer including lithology, porosity and water content resulting from precipitation gave the lowest estimates of ablation, ranging from $0.38 \mathrm{~m}$ w.e. at $\mathrm{KH} 1$ to $1.04 \mathrm{~m}$ w.e. at $\mathrm{KH} 4$ for dry debris. The values for moist debris were even lower, equivalent to $33-46 \%$ of the dry values from three sites. The simulated debris moisture content was likely overestimated by the numerical model, as we assumed that (i) all precipitation was liquid, which is not supported at least for the snowstorms in 2014 when snow accumulated on top of the debris, and (ii) the precipitation instantly infiltrated the debris layer without any loss due to vapour fluxes at the surface and within the debris, which have been shown to be non-negligible (Collier et al. 2014; Evatt et al. 2015). In addition, the distribution of water and ice within moist debris layers is not prognosed by the model, and therefore the temperature of all such layers is constrained at the upper bound at the melting point if ice is present within the pore spaces of the debris. These simplifications may overestimate the debris water content available for re-freezing and forming ice within the debris pore spaces at the beginning of the monsoon period, as well as the impact of the presence of interstitial ice near the base of the debris, and therefore the strong reduction in sub-debris ablation between dry and moist simulations.

\subsection{Contribution of sub-debris ablation to glacier-wide mass balance}

705 Multi-temporal satellite observations of glacier topography can be used to infer mass balance where the complete coverage of glacier surfaces negates the need to consider vertical ice fluxes (e.g. Bolch et al., 2011; King et al., 2017). We can compare observations of surface lowering in the debris-covered ablation areas with our sub-debris ablation values if the emergence velocities of the ice are known ( $c f$. Vincent et al., 2016). Numerical modelling of ice flow through Khumbu Glacier can be used to derive a depth-integrated velocity field for the entire glacier. Using results from Rowan et al. (2015), the mean emergence velocity across the debris-covered section of Khumbu Glacier is estimated to be $0.50 \mathrm{~m} \mathrm{a}^{-1}$, slightly lower than $0.74 \mathrm{~m} \mathrm{a}^{-1}$ for the entire ablation area beneath the icefall. These values describe ice flux, so conversion to water equivalent using the same value as King et al. (2017) for the density of glacier ice $\left(850 \mathrm{~kg} \mathrm{~m}^{-3}\right)$ gives $0.45 \mathrm{~m}$ w.e. $\mathrm{a}^{-1}$ for the debris-covered section, similar to the value of 0.37 $\mathrm{m}$ w.e. $\mathrm{a}^{-1}$ calculated by Vincent et al. (2016) for Changri Nup Glacier. Surface lowering rates observed between 2000 and 2015 were up to $1.06 \pm 0.10 \mathrm{~m} \mathrm{a}^{-1}$ at the altitudes of the ablation area of the large debris-covered glaciers in Everest region (Dudh Koshi catchment) and slightly higher for the lower ablation area of Khumbu Glacier, reaching up to $1.39 \pm 0.14 \mathrm{~m} \mathrm{a}^{-1}$ at altitudes of $5100-5200 \mathrm{~m}$ (King et 
The Cryosphere Discuss., https://doi.org/10.5194/tc-2017-239

Manuscript under review for journal The Cryosphere

Discussion started: 30 November 2017

(c) Author(s) 2017. CC BY 4.0 License.

al., 2017). We assume that surface lowering values represent loss of ice rather than reduced supraglacial debris thickness, and compare our estimates of ablation with remote observations of glacier-wide surface lowering by King et al. (2017).

For Khumbu Glacier, mean observed surface lowering for the debris-covered section was $1.14 \pm 0.12 \mathrm{~m}$ $\mathrm{a}^{-1}$ between 2009 and 2015 (King et al., 2017). Combining observed surface lowering with modelled mean emergence flux give a total loss of ice thickness of $1.59 \mathrm{~m} \mathrm{a}^{-1}$. Ablation calculated using the thermal diffusion model gave lower values than those observed remotely; mean surface lowering beneath thick, moist debris was $0.12-0.17 \mathrm{~m} \mathrm{a}^{-1}$ and $0.56 \mathrm{~m} \mathrm{a}^{-1}$ beneath thin, moist debris. If the debris layer was dry, then surface lowering would be $0.09 \mathrm{~m} \mathrm{a}^{-1}$ if calculated using glacier-specific $k$ of $0.98 \pm$ $0.1 \mathrm{~W} \mathrm{~m}^{-1}{ }^{\circ} \mathrm{C}^{-1}$, and $0.35 \mathrm{~m} \mathrm{a}^{-1}$ if calculated using a generic whole-rock $k$ value $\left(2.5 \mathrm{~W} \mathrm{~m}^{-1}{ }^{\circ} \mathrm{C}^{-1}\right)$. For Ngozumpa Glacier, mean surface lowering from King et al. (2017) for the debris-covered section was $1.21 \pm 0.13 \mathrm{~m} \mathrm{a}^{-1}$ between 2010 and 2015 , assuming that the emergence velocity is zero across the lower ablation area. Similar results are presented by Thompson et al. (2016) who measured mean surface lowering for the lower ablation area that includes NG1 between June 2010 and December 2012 (19 months) of $1.8 \pm 0.11 \mathrm{~m}$, equivalent to $1.1 \pm 0.11 \mathrm{~m} \mathrm{a}^{-1}$, and between December 2012 and January 2015 (12 months) of $1.3 \pm 0.32 \mathrm{~m} \mathrm{a}^{-1}$. Simulated ablation gave surface lowering beneath thick, dry debris of $0.38 \mathrm{~m} \mathrm{a}^{-1}$ if calculated using glacier-specific $k$ of $1.43 \pm 0.14 \mathrm{~W} \mathrm{~m}^{-1}{ }^{\circ} \mathrm{C}^{-1}$ or $0.74 \mathrm{~m} \mathrm{a}^{-1} \mathrm{using}$ generic whole-rock $k$.

These results indicate that for both Khumbu and Ngozumpa Glaciers the total annual loss of mass beneath thick debris $\left(0.12-0.74 \mathrm{~m} \mathrm{a}^{-1}\right)$ for moist and dry debris is less than observed surface lowering (1.21-1.59 $\left.\mathrm{m} \mathrm{a}^{-1}\right)$. The observed level of mass loss suggests that even if a substantial proportion of the debris-covered area is thinner than $0.5 \mathrm{~m}$, about $65 \%$ (and up to $90 \%$ if the debris is thick) of the surface lowering at Khumbu Glacier at ice cliffs and supraglacial ponds and by englacial melt and conduit collapse. Although ice cliffs occupy only a small proportion of the ablation area of each glacier, their occurrence is positively correlated with surface lowering (Watson et al. 2017). Remote mapping of debris thickness across Khumbu Glacier using thermal satellite imagery indicates that $73 \%$ of the debris layer could be sufficiently thin (less than $0.3 \mathrm{~m}$ thick) to make the lower figure plausible, but estimate that the mean thickness is $0.65 \pm 1.75 \mathrm{~m}$ (Soncini et al., 2016). Our field measurements also suggest greater debris thicknesses are typical in the ablation area, with a mean of $0.84 \pm 0.32 \mathrm{~m}(n=143)$ and only $15 \%$ of the sampled points with thicknesses less than $0.3 \mathrm{~m}$. If the glacier surface was not debris covered, we would expect still greater mass loss than current observations; Vincent et al. (2016) calculated a mass balance of $-3.0 \mathrm{~m}$ w.e. $\mathrm{a}^{-1}$ (equivalent to surface lowering of $3.90 \mathrm{~m} \mathrm{a}^{-1}$ if emergence is included) for the debris-covered section of Changri Nup Glacier by extrapolating from ablation stake measurements of the clean-ice section of this glacier to the elevation of the debris-covered tongue, 
The Cryosphere Discuss., https://doi.org/10.5194/tc-2017-239

Manuscript under review for journal The Cryosphere

Discussion started: 30 November 2017

(c) Author(s) 2017. CC BY 4.0 License.

755 which has a similar elevation to the upper ablation area of Khumbu Glacier. These results demonstrate that thick debris layers common to glaciers in the Everest region do act to preserve the underlying ice, although more rapid decay occurs due to enhanced mass loss around ice cliffs and supraglacial ponds than would be the case for an entirely debris-covered surface.

\section{Conclusions}

We compared on-glacier air, surface and supraglacial debris temperatures from 11 sites on three glaciers in the Everest region of Nepal. Debris layer temperatures, and therefore the amount of subdebris ablation, varied during the monsoon season as air temperatures rose and fell and large volumes of precipitation were deposited. The monsoon occurred between 3 June and 11 October in 2014 and similar periods in 2015 and 2016. Estimates of monsoon season ablation for debris layers with thicknesses of $1.5-0.3 \mathrm{~m}$ ranged from $0.10-0.47 \mathrm{~m}$ w.e. using the thermal diffusion model for moist debris to 0.68-2.67 $\mathrm{m}$ w.e. using the degree day factor approach driven by measurements of air temperature $\left(T_{a}\right)$. A calculation of downward heat flux gave intermediate values for ablation of $0.18-$ $1.84 \mathrm{~m} \mathrm{~m}$ w.e. for the 131-day monsoon season. In the absence of suitable direct validation data, these widely varying results illustrate that caution is required when choosing a method to estimate sub-debris ablation. The DDFs approach is site specific and relies upon the relationship between measured $T_{a}$ and the melt rate at the calculation site to be the same as the relationship from which the DDFs were developed. The downward heat flux approach applied here is reliant on the quality of the debris surface temperature $\left(T_{s}\right)$ measurements available, the validity of the assumption that all heat flux within the debris is conductive, and the degree to which the $k$ value used represents the bulk conditions within the porous debris cover over the period of calculation. The thermal diffusion model as set up here is also dependent upon the quality of the $T_{s}$ forcing data, but is able to, at least partially, account for nonconductive processes by including the impact of likely bulk phase changes of moisture within the debris cover. Although it remains unclear which of these methods can provide the most robust and reliable method at local, glacier or regional scales, the thermal diffusion model reproduced our observations of seasonal mean debris temperatures using a generic whole-rock $k$ value, and reproduced the results of the downward heat flux approach when used with glacier-specific bulk $k$ values.

We found that the seasonal debris temperature-depth profiles were strongly dependent on debris thickness and consistent between three different glaciers. These profiles were generally linear through debris layers at least $0.5 \mathrm{~m}$ thick. This observation simplifies the prediction of multiannual sub-debris ablation, which can therefore be estimated using a power-law relationship that is likely applicable to debris-covered glaciers in the monsoon-influenced Himalaya. The moist and dry thermal diffusion simulations and a calculation using downward heat flux gave similar results for sub-debris ablation across a range of debris thicknesses greater than $0.5 \mathrm{~m}$, but gave a wider range of values for thin $(<0.5$ 
The Cryosphere Discuss., https://doi.org/10.5194/tc-2017-239

Manuscript under review for journal The Cryosphere

Discussion started: 30 November 2017

(c) Author(s) 2017. CC BY 4.0 License.

m) debris layers. These results demonstrate the difficulty in estimating ablation beneath thin supraglacial debris, and the need to investigate the thermal properties these debris layers in more detail to calculate ablation. Debris-covered ice represents over a third of the glacierised area in the Everest region and the majority of this area appears to be covered by thick supraglacial debris rather than thin, patchy layers. Thick supraglacial debris tends to attenuate the flux of heat to the ice surface of debriscovered glaciers, and we have shown that this is predictable at a seasonal timescale. Numerical modelling of glacier evolution in response to climate change can apply the relationship observed here to improve predictions of regional multiannual glacier mass balance in future decades. However, comparison of our estimates of ablation with observations of glacier surface lowering indicates that subdebris ablation does not represent the majority of mass loss. Instead, over $65 \%$ of mass loss likely occurs where debris is thin $(<0.5 \mathrm{~m})$ or patchy and at the exposed faces of ice cliffs, beneath supraglacial ponds and englacially.

\section{Data availability}

All temperature data collected at Khumbu Glacier in 2014, 2015 and 2016 are available to download from the Pangaea repository: https://doi.pangaea.de/10.1594/PANGAEA.883071

\section{Author contributions}

810 AR and DQ designed the original study, planned and carried out the fieldwork at Khumbu Glacier. LN provided data collected at Ngozumpa Glacier in 2001/02 and carried out the downward heat flux calculations. EC carried out the thermal diffusion model simulations. MG, OK, SW and TDLIF contributed to data collection at Khumbu Glacier. PW provided meteorological data from the Pyramid Observatory. DR provided data collected at Imja-Lhotse Shar Glacier. ST provided data collected at

815 Ngozumpa Glacier in 2014-2016. OK provided surface lowering results. NG contributed to the study design. All authors contributed to discussion of the results and writing the manuscript.

\section{Competing interests}

The authors declare that they have no conflicts of interest.

\section{Acknowledgements}

Fieldwork at Khumbu Glacier was supported by Royal Society Research Grant RG120393 to A. Rowan and D. Quincey, and a grant from the Mount Everest Foundation to A. Rowan. L. Nicholson was supported by Austrian Science Fund (Project numbers V309 and P28521). Phil Porter is thanked for the loan of some of the equipment used. Yves Lejeune is thanked for processing precipitation data, and Pierre Chevallier for processing air temperature data collected at the Pyramid Observatory. The 
The Cryosphere Discuss., https://doi.org/10.5194/tc-2017-239

Manuscript under review for journal The Cryosphere

Discussion started: 30 November 2017

(c) Author(s) 2017. CC BY 4.0 License.

meteorological dataset contained within this study was collected within the framework of the Ev-K2-

CNR Project in collaboration with the Nepal Academy of Science and Technology as foreseen by the

Memorandum of Understanding between Nepal and Italy, and thanks to contributions from the Italian

National Research Council, the Italian Ministry of Education, University and Research and the Italian

Ministry of Foreign Affairs.

\section{References}

Azam, M. F., Wagnon, P., Vincent, C., Ramanathan, A., Linda, A. and Singh, V. B.: Reconstruction of the annual mass balance of Chhota Shigri glacier, Western Himalaya, India, since 1969, Annals of Glaciology, 55(66), 69-80, doi:10.3189/2014AoG66A104, 2014.

Benn, D. I. and Lehmkuhl, F.: Mass balance and equilibrium-line altitudes of glaciers in high-mountain environments, Quaternary International, 65, 15-29, 2000.

840 Benn, D., Bolch, T., Hands, K., Gulley, J., Luckman, A., Nicholson, L. I., Quincey, D., Thompson, S., Toumi, R. and Wiseman, S.: Response of debris-covered glaciers in the Mount Everest region to recent warming, and implications for outburst flood hazards, Earth Science Reviews, 114, 156174, doi:10.1016/j.earscirev.2012.03.008, 2012.

Bolch, T., Kulkarni, A., Kääb, A., Huggel, C., Paul, F., Cogley, J. G., Frey, H., Kargel, J. S., Fujita, K., Scheel, M., Bajracharya, S. and Stoffel, M.: The State and Fate of Himalayan Glaciers, Science, 336(6079), 310-314, doi:10.1126/science.1215828, 2012.

Bolch, T., Pieczonka, T. and Benn, D. I.: Multi-decadal mass loss of glaciers in the Everest area (Nepal Himalaya) derived from stereo imagery, The Cryosphere, 5(2), 349-358, doi:10.5194/tc-5-3492011, 2011.

Bollasina, M., Bertolani, L. and Tartari, G.: Meteorological observations at high altitude in the Khumbu Valley, Nepal Himalayas, 1994-1999, Seppyo, 19, 1-11, 2002.

Bonasoni, P., Laj, P., Marinoni, A., Sprenger, M., Angelini, F., Arduini, J., Bonafè, U., Calzolari, F., Colombo, T., Decesari, S., Di Biagio, C., di Sarra, A. G., Evangelisti, F., Duchi, R., Facchini, M. C., Fuzzi, S., Gobbi, G. P., Maione, M., Panday, A., Roccato, F., Sellegri, K., Venzac, H., Verza, G. P., Villani, P., Vuillermoz, E. and Cristofanelli, P.: Atmospheric Brown Clouds in the Himalayas: first two years of continuous observations at the Nepal Climate Observatory-Pyramid (5079 m), Atmos. Chem. Phys., 10(15), 7515-7531, doi:10.5194/acp-10-7515-2010, 2010.

Brock, B. W., Mihalcea, C., Kirkbride, M. P., Diolaiuti, G., Cutler, M. E. J. and Smiraglia, C.: Meteorology and surface energy fluxes in the 2005-2007 ablation seasons at the Miage debriscovered glacier, Mont Blanc Massif, Italian Alps, J. Geophys. Res, 115(D9), D09106-17, doi:10.1029/2009JD013224, 2010.

Brun, F., Berthier, E., Wagnon, P., Kääb, A., \& Treichler, D. (2017). A spatially resolved estimate of High Mountain Asia glacier mass balances from 2000 to 2016. Nature Geoscience, 482, 514-7.

Carenzo, M., Pellicciotti, F., Mabillard, J., Reid, T. and Brock, B. W.: An enhanced temperature index model for debris-covered glaciers accounting for thickness effect, Advances in Water Resources, 94(C), 457-469, doi:10.1016/j.advwatres.2016.05.001, 2016.

Collier, E., Maussion, F., Nicholson, L. I., Molg, T., Immerzeel, W. W. and Bush, A. B. G.: Impact of debris cover on glacier ablation and atmosphere-glacier feedbacks in the Karakoram, The Cryosphere, 9(4), 1617-1632, doi:10.5194/tc-9-1617-2015, 2015.

870 Collier, E., Nicholson, L. I., Brock, B. W., Maussion, F., Essery, R. and Bush, A. B. G.: Representing moisture fluxes and phase changes in glacier debris cover using a reservoir approach, The Cryosphere, 8(4), 1429-1444, doi:10.5194/tc-8-1429-2014, 2014.

Conway, H. and Rasmussen, L. A.: Summer temperature profiles within supraglacial debris on Khumbu Glacier, Nepal, IAHS Publ. 264 (Symposium at Seattle 2000 - Debris-Covered Glaciers), 264, 89, 8752000.

Evatt, G. W., Abrahams, I. D., Heil, M. and Mayer, C.: Glacial melt under a porous debris layer, 
The Cryosphere Discuss., https://doi.org/10.5194/tc-2017-239

Manuscript under review for journal The Cryosphere

Discussion started: 30 November 2017

(c) Author(s) 2017. CC BY 4.0 License.

Journal of Glaciology, 61(229), 825-836, 2015.

Gardelle, J., Berthier, E., Arnaud, Y. and Kääb, A.: Region-wide glacier mass balances over the PamirKarakoram-Himalaya during 1999-2011, The Cryosphere, 7(4), 1263-1286, doi:10.5194/tc-7-

880 1263-2013, 2013.

Gibson, M.J., Irvine-Fynn, T.D.L., Wagnon, P., Rowan, A.V., Quincey, D., Homer, R., Glasser, N. Variations in near-surface debris temperature through the summer monsoon on Khumbu Glacier, Nepal Himalaya. Earth Surface Processes and Landforms (2017, in revision)

Hambrey, M. J., Quincey, D. J., Glasser, N. F., Reynolds, J. M., Richardson, S. J. and Clemmens, S.: Sedimentological, geomorphological and dynamic context of debris-mantled glaciers, Mount Everest (Sagarmatha) region, Nepal, Quaternary Science Reviews, 27(25-26), 2361-2389, doi:10.1016/j.quascirev.2008.08.010, 2008.

Immerzeel, W. W., Kraaijenbrink, P. D. A., Shea, J. M., Shrestha, A. B., Pellicciotti, F., Bierkens, M. F. P. and de Jong, S. M.: High-resolution monitoring of Himalayan glacier dynamics using unmanned aerial vehicles, Remote Sensing of Environment, 150(C), 93-103, doi:10.1016/j.rse.2014.04.025, 2013.

Immerzeel, W. W., van Beek, L. P. H. and Bierkens, M. F. P.: Climate Change Will Affect the Asian Water Towers, Science, 328(5984), 1382-1385, doi:10.1126/science.1183188, 2010.

Inoue, J.: Mass Budget of Khumbu Glacier: Glaciological Expedition of Nepal, Contribution No. 32, Seppyo, 39, 15-19, 1977.

Juen, M., Mayer, C., Lambrecht, A., Han, H. and Liu, S.: Impact of varying debris cover thickness on ablation: a case study for Koxkar Glacier in the Tien Shan, The Cryosphere, 8(2), 377-386, doi:10.5194/tc-8-377-2014, 2014.

Kayastha, R. B., Takeuchi, Y., Nakawo, M. and Ageta, Y.: Practical prediction of ice melting beneath various thickness of debris cover on Khumbu Glacier, Nepal, using a positive degree-day factor, Debris-covered glaciers: proceedings of an international workshop held at the University of Washington in Seattle, Washington, USA, 13-15 September 2000, 1-82, 2000.

Kääb, A., Berthier, E., Nuth, C., Gardelle, J. and Arnaud, Y.: Contrasting patterns of early twenty-firstcentury glacier mass change in the Himalayas, Nature, 488(7412), 495-498, doi:10.1038/nature11324, 2012.

King, O., Quincey, D. J. and Carrivick, J. L.: Spatial variability in mass loss of glaciers in the Everest region, central Himalayas, between 2000 and 2015, The Cryosphere, 11, doi:10.5194/tc-11-12017, 2017.

Kraaijenbrink, P. D. A., Bierkens, M. F. P., Lutz, A. F., \& Immerzeel, W. W. (2017). Impact of a global temperature rise of 1.5 degrees Celsius on Asia's glaciers. Nature, 549(7671), 257-260.

Mattson, L., Gardner, J. and Young, G.: Ablation on debris covered glaciers: an example from the Rakhiot Glacier, Punjab, Himalaya, IAHS Publications, 218, 289-296, 1993.

McCarthy, M., Pritchard, H., Willis, I. and King, E.: Ground-penetrating radar measurements of debris thickness on Lirung Glacier, Nepal, Journal of Glaciology, 63(239), 543-555,

915 doi:10.1017/jog.2017.18, 2017.

Mihalcea, C., Mayer, C., Diolaiuti, G., D'Agata, C., Smiraglia, C., Lambrecht, A., Vuillermoz, E. and Tartari, G.: Spatial distribution of debris thickness and melting from remote-sensing and meteorological data, at debris-covered Baltoro glacier, Karakoram, Pakistan, Annals of Glaciology, 48(1), 49-57, 2008.

Mihalcea, C., Mayer, C., Diolaiuti, G., Lambrecht, A., Smiraglia, C. and Tartari, G.: Ice ablation and meteorological conditions on the debris-covered area of Baltoro glacier, Karakoram, Pakistan, Annals of Glaciology, 43(1), 292-300, 2006.

Nakawo, M., Iwata, S., Watanabe, O. and Yoshida, M.: Processes which distribute supraglacial debris on the Khumbu Glacier, Nepal Himalaya, Annals of Glaciology, 8, 129-131, 1986.

Nicholson, L. 2005. Modelling melt beneath supraglacial debris: implications for the climatic response of debris-covered glaciers. ( $\mathrm{PhD}$ thesis, University of St Andrews.)

Nicholson, L. and Benn, D.: Calculating ice melt beneath a debris layer using meteorological data, Journal of Glaciology, 52(178), 463-470, 2006.

Nicholson, L. and Benn, D. I.: Properties of natural supraglacial debris in relation to modelling subdebris ice ablation, Earth Surf. Process. Landforms, 38(5), 490-501, doi:10.1002/esp.3299, 2013. 
The Cryosphere Discuss., https://doi.org/10.5194/tc-2017-239

Manuscript under review for journal The Cryosphere

Discussion started: 30 November 2017

(c) Author(s) 2017. CC BY 4.0 License.

Østrem, G.: Ice melting under a thin layer of moraine, and the existence of ice cores in moraine ridges, Geografiska Annaler, 41(4), 228-230, 1959.

Quincey, D. J., Luckman, A. and Benn, D.: Quantification of Everest region glacier velocities between 1992 and 2002, using satellite radar interferometry and feature tracking, Journal of Glaciology, 55(192), 596-606, 2009.

RGI Consortium, 2017, Randolph Glacier Inventory (RGI) - A Dataset of Global Glacier Outlines: Version 6.0. Technical Report, Global Land Ice Measurements from Space, Boulder, Colorado, USA. Digital Media. DOI: https://doi.org/10.7265/N5-RGI-60.

Ragettli, S., Pellicciotti, F., Immerzeel, W. W., Miles, E. S., Petersen, L., Heynen, M., Shea, J. M., 940 Stumm, D., Joshi, S. and Shrestha, A.: Unraveling the hydrology of a Himalayan catchment through integration of high resolution in situ data and remote sensing with an advanced simulation model, 78(C), 94-111, doi:10.1016/j.advwatres.2015.01.013, 2015.

Ragettli, S., Immerzeel, W. W., \& Pellicciotti, F.: Contrasting climate change impact on river flows from high-altitude catchments in the Himalayan and Andes Mountains. Proceedings of the National Academy of Sciences, 113, 9222-9227. http://doi.org/10.1073/pnas.1606526113, 2016.

Reid, T. D. and Brock, B. W.: An energy-balance model for debris-covered glaciers including heat conduction through the debris layer, Journal of Glaciology, 56(199), 903-916, 2010.

Reid, T. D., Carenzo, M., Pellicciotti, F. and Brock, B. W.: Including debris cover effects in a distributed model of glacier ablation, J. Geophys. Res, 117(D18), doi:10.1029/2012JD017795, 2012.

Rounce, D. R. and McKinney, D. C.: Debris thickness of glaciers in the Everest area (Nepal Himalaya) derived from satellite imagery using a nonlinear energy balance model, The Cryosphere, 8(4), 1317-1329, doi:10.5194/tc-8-1317-2014, 2014.

Rounce, D. R., Quincey, D. J. and McKinney, D. C.: Debris-covered glacier energy balance model for Imja-Lhotse Shar Glacier in the Everest region of Nepal, The Cryosphere, 9(6), 2295-2310, doi:10.5194/tc-9-2295-2015, 2015.

Rowan, A. V., Egholm, D. L., Quincey, D. J. and Glasser, N. F.: Modelling the feedbacks between mass balance, ice flow and debris transport to predict the response to climate change of debris-covered glaciers in the Himalaya, Earth and Planetary Science Letters, 430(C), 427-438, doi:10.1016/j.eps1.2015.09.004, 2015.

Scherler, D., Bookhagen, B. and Strecker, M. R.: Spatially variable response of Himalayan glaciers to climate change affected by debris cover, Nature Geosci, 4, 156-159, doi:10.1038/ngeo1068, 2011.

Shea, J. M., Wagnon, P., Immerzeel, W. W., Biron, R., Brun, F. and Pellicciotti, F.: A comparative high-altitude meteorological analysis from three catchments in the Nepalese Himalaya, International Journal of Water Resources Development, 1-27, doi:10.1080/07900627.2015.1020417, 2015.

Sherpa, S. F., Wagnon, P., Brun, F., Berthier, E., Vincent, C., Lejeune, Y., Arnaud, Y., Kayastha, R. B. and Sinisalo, A.: Contrasted surface mass balances of debris-free glaciers observed between the southern and the inner parts of the Everest region (2007-15), Journal of Glaciology, 131, 1-15, doi:10.1017/jog.2017.30, 2017.

Soncini, A., Bocchiola, D., Confortola, G., Minora, U., Vuillermoz, E., Salerno, F., Viviano, G., Shrestha, D., Senese, A., Smiraglia, C. and Diolaiuti, G.: Future hydrological regimes and glacier cover in the Everest region: The case study of the upper Dudh Koshi basin, Science of the Total Environment, The, 1-18, doi:10.1016/j.scitotenv.2016.05.138, 2016.

Steiner, J. F. and Pellicciotti, F.: Variability of air temperature over a debris-covered glacier in the Nepalese Himalaya, Annals of Glaciology, 57(71), 295-307, doi:10.3189/2016AoG71A066, 2016.

Thakuri, S., Salerno, F., Smiraglia, C., Bolch, T., D'Agata, C., Viviano, G. and Tartari, G.: Tracing glacier changes since the 1960s on the south slope of Mt. Everest (central Southern Himalaya) using optical satellite imagery, The Cryosphere, 8(4), 1297-1315, doi:10.5194/tc-8-1297-2014, 2014.

Thompson, S., Benn, D. I., Mertes, J. and Luckman, A.: Stagnation and mass loss on a Himalayan debris-covered glacier: processes, patterns and rates, Journal of Glaciology, 1-19, 2016.

Vincent, C., Wagnon, P., Shea, J. M., Immerzeel, W. W., Kraaijenbrink, P., Shrestha, D., Soruco, A., 
The Cryosphere Discuss., https://doi.org/10.5194/tc-2017-239

Manuscript under review for journal The Cryosphere

Discussion started: 30 November 2017

(c) Author(s) 2017. CC BY 4.0 License.

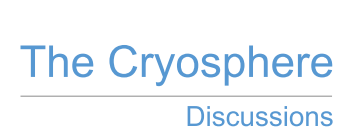

(c) (i)

985 Arnaud, Y., Brun, F., Berthier, E. and Sherpa, S. F.: Reduced melt on debris-covered glaciers: investigations from Changri Nup Glacier, Nepal, The Cryosphere, 10(4), 1845-1858, doi:10.5194/tc-10-1845-2016, 2016.

Watson, C. S., Quincey, D. J., Carrivick, J. L. and Smith, M. W.: The dynamics of supraglacial water storage in the Everest region, central Himalaya, Global and Planetary Change, 142, 14-27, doi:10.1016/j.gloplacha.2016.04.008, 2017.

990

Westoby, M. J., Glasser, N. F., Hambrey, M. J., Brasington, J., Reynolds, J. M. and Hassan, M. A. A. M.: Reconstructing historic Glacial Lake Outburst Floods through numerical modelling and geomorphological assessment: Extreme events in the Himalaya, Earth Surf. Process. Landforms, 39(12), n/a-n/a, doi:10.1002/esp.3617, 2014.

995 Yao, T., Thompson, L., Yang, W., Yu, W., Gao, Y., Guo, X., Yang, X., Duan, K., Zhao, H., Xu, B., Pu, J., Lu, A., Xiang, Y., Kattel, D. B. and Joswiak, D.: Different glacier status with atmospheric circulations in Tibetan Plateau and surroundings, Nature Climate Change, 2(7), 1-5, doi:10.1038/nclimate1580, 2012. 
The Cryosphere Discuss., https://doi.org/10.5194/tc-2017-239

Manuscript under review for journal The Cryosphere

Discussion started: 30 November 2017

(c) Author(s) 2017. CC BY 4.0 License.

Table 1. Description of the data collection sites on Khumbu, Ngozumpa and Imja-Lhotse Shar Glaciers in the Everest region of Nepal. Debris thickness values in italics are estimated where the debris layer was too thick to excavate to the debris-ice interface

\begin{tabular}{|c|c|c|c|c|c|}
\hline Site ID & $\begin{array}{l}\text { Altitude } \\
\text { (m) }\end{array}$ & $\begin{array}{l}\text { Distance from } \\
\text { terminus }(\mathrm{km})\end{array}$ & $\begin{array}{l}\text { Debris } \\
\text { thickness } \\
(\mathrm{m})\end{array}$ & $\begin{array}{l}\text { Duration of data } \\
\text { collection }\end{array}$ & Seasons measured \\
\hline $\mathrm{KH} 1$ & 4935 & $1.4 \mathrm{~N}$ & 1.50 & $10 / 05 / 14$ to $12 / 11 / 14$ & Summer 2014 \\
\hline $\mathrm{KH} 1$ & 4935 & $1.4 \mathrm{~N}$ & 1.50 & $21 / 11 / 14$ to $20 / 10 / 15$ & Winter 2014 \& Summer 2015 \\
\hline $\mathrm{KH} 2$ & 4958 & $2.5 \mathrm{~N}$ & 0.70 & $13 / 05 / 14$ to $13 / 11 / 14$ & Summer 2014 \\
\hline $\mathrm{KH} 2$ & 4958 & $2.5 \mathrm{~N}$ & 0.70 & $20 / 10 / 15$ to $22 / 09 / 16$ & Winter 2015 \& Summer 2016 \\
\hline $\mathrm{KH} 3$ & 4954 & 3.7 NE & 0.80 & $17 / 05 / 14$ to $15 / 11 / 14$ & Summer 2014 \\
\hline $\mathrm{KH} 4$ & 5180 & $6.8 \mathrm{~N}$ & 0.30 & $20 / 05 / 14$ to $16 / 11 / 14$ & Summer 2014 \\
\hline KH5 & 4943 & $2.1 \mathrm{~S}$ & 0.70 & $20 / 10 / 15$ to $12 / 05 / 16$ & Winter 2015 \\
\hline NG1 & 4800 & $1.5 \mathrm{~N}$ & 2.00 & $13 / 11 / 01$ to $12 / 10 / 02$ & Winter 2001 \& Summer 2002 \\
\hline NG2 & 4725 & 1.6 WSW & 1.75 & $04 / 11 / 14$ to $03 / 04 / 16$ & Winter 2014 , Summer 2015 and Winter 2015 \\
\hline IM4 & 5050 & $1.0 \mathrm{SW}$ & 1.50 & $31 / 05 / 14$ to $09 / 11 / 14$ & Summer 2014 \\
\hline IM11 & 5050 & $1.0 \mathrm{~S}$ & 0.45 & $31 / 05 / 14$ to $09 / 11 / 14$ & Summer 2014 \\
\hline IM13 & 5050 & $1.0 \mathrm{NE}$ & 0.33 & $31 / 05 / 14$ to $09 / 11 / 14$ & Summer 2014 \\
\hline IM14 & 5050 & $1.0 \mathrm{SE}$ & 0.26 & $31 / 05 / 14$ to $09 / 11 / 14$ & Summer 2014 \\
\hline
\end{tabular}

1005 Table 2. Examples of bulk effective thermal conductivity $(k)$ values for debris-covered glaciers in Nepal and Europe

\begin{tabular}{|c|c|c|c|c|c|c|c|c|}
\hline Glacier & Country & $\begin{array}{l}\text { Latitude } \\
\left({ }^{\circ} \mathrm{N}\right)\end{array}$ & $\begin{array}{l}\text { Debris } \\
\text { lithology }\end{array}$ & $\begin{array}{c}\text { Debris } \\
\text { thickness (m) }\end{array}$ & $\begin{array}{c}\text { Effective thermal } \\
\text { conductivity }\left(\mathrm{W} \mathrm{m}^{-1}{ }^{\circ} \mathrm{C}^{-1}\right)\end{array}$ & $\begin{array}{l}\text { Assumed } \\
\text { debris water } \\
\text { content (\%) }\end{array}$ & Measurement period & Reference \\
\hline Larsbreen & Svalbard & 78 & Sedimentary & 0.65 & $0.59 \pm 0.12$ & Dry & 9-20 July 2002 & 2 Nicholson and Benn (2006) \\
\hline Larsbreen & Svalbard & 78 & Sedimentary & 0.65 & $1.67 \pm 0.35$ & Wet & 9-20 July 2002 & 2 Nicholson and Benn (2006) \\
\hline Haut Glacier d'Arolla & Switzerland & 46 & Granitic & 0.06 & $1.02 \pm 0.1$ & & 28 July-11 September 2010 & 0 Reid et al. (2012) \\
\hline Miage & Italy & 45 & Granitic & 0.23 & 0.94 & & 21 June-4 September 2005-2007 & 7 Reid and Brock (2010) \\
\hline Belvedere & Italy & 45 & Metamorphic & 0.27 & $0.64 \pm 0.07$ & Dry & 6-10 August 2003 & 3 Nicholson and Benn (2006) \\
\hline Belvedere & Italy & 45 & Metamorphic & 0.27 & $1.78 \pm 0.19$ & Wet & 6-10 August 2003 & 3 Nicholson and Benn (2006) \\
\hline Imja-Lhotse Shar & Nepal & 28 & Granitic & 0.47 & $0.96 \pm 0.33$ & Dry & 15-24 September 2013 & 3 Rounce and McKinney (2014) \\
\hline Imja-Lhotse Shar & Nepal & 28 & Granitic & 1.50 & $1.44 \pm 0.14$ & 33 & 2 June-12 October 2014 & 4 Rounce et al. (2015) \\
\hline Imja-Lhotse Shar & Nepal & 28 & Granitic & 0.45 & $1.62 \pm 0.16$ & 33 & 2 June-12 October 2014 & 4 Rounce et al. (2015) \\
\hline Imja-Lhotse Shar & Nepal & 28 & Granitic & 0.33 & $0.47 \pm 0.04$ & 33 & 2 June-12 October 2014 & 4 Rounce et al. (2015) \\
\hline $\begin{array}{l}\text { Ngozumpa } \\
\text {. }\end{array}$ & Nepal & 27 & Granitic & 2.00 & $1.36 \pm 0.14$ & $\begin{array}{r}50 \\
0\end{array}$ & Summer (JJA) & 1) Nicholson and Benn (2012) \\
\hline Ngozumpa & Nepal & 27 & Granitic & 2.00 & $1.00 \pm 0.10$ & 0 & Winter (DJF) & Nicholson and Benn (2012) \\
\hline Ngozumpa & Nepal & 27 & Granitic & 2.00 & $1.42 \pm 0.14$ & 10 & Summer (JJA) & 1) Nicholson and Benn (2012) \\
\hline Ngozumpa & Nepal & 27 & Granitic & 2.00 & $0.99 \pm 0.09$ & 10 & Winter (DJF) & Nicholson and Benn (2012) \\
\hline Ngozumpa & Nepal & 27 & Granitic & 2.00 & $1.55 \pm 0.15$ & 20 & Summer (JJA) & Nicholson and Benn (2012) \\
\hline Ngozumpa & Nepal & 27 & Granitic & 2.00 & $1.04 \pm 0.10$ & 20 & Winter (DJF) & Nicholson and Benn (2012) \\
\hline Khumbu & Nepal & 27 & Granitic & 0.40 & $0.85 \pm 0.20$ & Dry & 19 May-3 June 1999 & 9 Conway and Rasmussen (2000) \\
\hline Khumbu & Nepal & 27 & Granitic & 2.50 & $1.28 \pm 0.15$ & Dry & 19 May-3 June 1999 & 9 Conway and Rasmussen (2000) \\
\hline
\end{tabular}

1010 Table 3. Division of the 2014 monsoon season into intervals based on air temperatures and precipitation amount measured at Khumbu Glacier and the Pyramid Observatory

\begin{tabular}{lllll}
\hline Interval & Date & $\begin{array}{l}\text { Day of Year } \\
\text { (inclusive) }\end{array}$ & $\begin{array}{l}\text { Duration } \\
\text { (days) }\end{array}$ & Characteristics \\
\hline Pre-monsoon & 25 May to 2 June & $145-153$ & 9 & Low air temperatures, high precipitation and snowstorms \\
Early monsoon & 3 June to 15 July & $154-196$ & 43 & Rising air temperatures, lower and more variable precipitation \\
Middle monsoon & 16 July to 25 September & $197-268$ & 72 & High air temperatures, precipitation occurs on most days \\
Late monsoon & 26 September to 11 October & $269-284$ & 16 & Falling air temperatures, low precipitation \\
Post-monsoon & 12 October to 19 October & $285-292$ & 8 & Low air temperatures, high precipitation and snowstorms \\
\hline
\end{tabular}


The Cryosphere Discuss., https://doi.org/10.5194/tc-2017-239

Manuscript under review for journal The Cryosphere

Discussion started: 30 November 2017

(c) Author(s) 2017. CC BY 4.0 License.

Table 4. Thermal properties of the debris layer at Khumbu, Ngozumpa and Imja Glaciers, and ablation calculated for each site using the DDFs and downward heat flux methods discussed in the text. Debris thickness values in italics are estimated where the debris layer was too thick to excavate to the debris-ice interface

\begin{tabular}{|c|c|c|c|c|c|c|c|c|c|c|c|c|c|c|c|c|}
\hline \multirow[b]{3}{*}{ Site } & \multirow[b]{3}{*}{ Year } & \multirow[b]{3}{*}{$\begin{array}{l}\text { Debris } \\
\text { thickness (m) }\end{array}$} & \multirow[b]{3}{*}{$\begin{array}{l}\text { Ablation from } \\
\text { stake } \\
\text { measurements } \\
\text { (mm w.e.) }\end{array}$} & \multirow[b]{3}{*}{$\begin{array}{l}\text { Glacier- } \\
\text { specific } \\
\text { bulk } k(\mathrm{~W} \\
\left.\mathrm{m}^{-1}{ }^{\circ} \mathrm{C}^{-1}\right)\end{array}$} & \multirow{2}{*}{\multicolumn{2}{|c|}{$\delta \mathrm{T}_{\mathrm{d}} / \delta \mathrm{h}_{\mathrm{d}}\left({ }^{\circ} \mathrm{C} \mathrm{m}^{-1}\right)$}} & \multirow{2}{*}{\multicolumn{2}{|c|}{ Mean $\mathrm{T}_{\mathrm{s}}$}} & \multirow{2}{*}{\multicolumn{2}{|c|}{ Mean $T_{i}$}} & \multirow{2}{*}{\multicolumn{3}{|c|}{ Ablation calculated using DDFs }} & \multirow{2}{*}{\multicolumn{3}{|c|}{$\begin{array}{l}\text { Ablation calculated using } \\
\text { downward heat flux }\end{array}$}} \\
\hline & & & & & & & & & & & & & & & & \\
\hline & & & & & Summer & Winter & Summer & Winter & Summer & Winter & $\begin{array}{c}\text { Total PDD } \\
\text { during } \\
\text { monsoon } \\
\text { season }\left({ }^{\circ} \mathrm{C}\right)\end{array}$ & 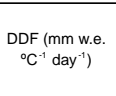 & $\begin{array}{l}\text { Total } \\
\text { ablation } \\
\text { (mm w.e.) }\end{array}$ & $\begin{array}{c}\text { Mean daily } \\
\mathrm{T}_{\mathrm{s}} \text { during } \\
\text { the } \\
\text { monsoon } \\
\text { season }\end{array}$ & 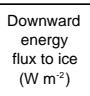 & $\begin{array}{c}\text { Total } \\
\text { ablation } \\
\text { (mm } \\
\text { w.e.) }\end{array}$ \\
\hline KH1 & 2014 & 1.50 & & $0.98 \pm 0.1$ & -2.6 & 1.3 & 7.1 & -5.3 & & & 524 & 2.73 & 1433 & 8.8 & 5.7 & 216 \\
\hline $\mathrm{KH} 1$ & 2015 & 1.50 & - & $0.98 \pm 0.1$ & -2.7 & 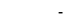 & 8.8 & - & - & - & 505 & 2.73 & 1381 & 7.5 & 4.9 & 184 \\
\hline KH2 & 2014 & 0.70 & - & $0.98 \pm 0.1$ & -5.8 & 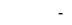 & 5.6 & & 1.7 & & 486 & 4.24 & 2063 & 7.0 & 9.8 & 369 \\
\hline $\mathrm{KH} 2$ & 2016 & 0.70 & & & & -1.4 & & -1.9 & & -3.0 & & & & & & \\
\hline $\mathrm{KH} 3$ & 2014 & & - & & & - & & - & & - & & - & & 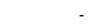 & 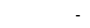 & \\
\hline $\mathrm{KH} 4$ & 2014 & 0.30 & - & $0.98 \pm 0.1$ & -16.7 & - & 5.0 & & -0.2 & & 386 & 6.92 & 2672 & 6.8 & 22.2 & 836 \\
\hline KH5 & 2015 & 0.70 & - & & & -0.4 & & -3.4 & - & -3.0 & & & & & & \\
\hline NG1 & 2002 & 2.00 & & $1.43 \pm 0.14$ & -4.5 & 2.0 & 9.2 & & & & 436 & 2.32 & 1010 & 8.4 & 6.0 & 226 \\
\hline NG2 & 2015 & 1.80 & & $1.43 \pm 0.14$ & -2.9 & 0.3 & 5.9 & -2.8 & 1.0 & -2.4 & 436 & 2.30 & 1003 & 7.0 & 5.6 & 209 \\
\hline IM4 & 2014 & 1.50 & & $1.98 \pm 0.2$ & -5.2 & & 8.2 & -3.6 & & & 291 & 2.73 & 796 & 10.6 & 14.0 & 527 \\
\hline IM11 & 2014 & 0.45 & $>1000$ & $1.98 \pm 0.2$ & -16.2 & . & 5.9 & - & - & - & 291 & 5.48 & 1594 & 7.6 & 33.4 & 1259 \\
\hline IM13 & 2014 & 0.33 & 850 & & -21.4 & - & 5.2 & - & - & - & 291 & 6.55 & 1906 & 7.8 & 46.8 & 1762 \\
\hline IM14 & 2014 & 0.26 & $>1000$ & $1.98 \pm 0.2$ & -18.6 & - & 5.1 & - & - & - & 291 & 7.52 & 2188 & 6.4 & 48.7 & 1835 \\
\hline
\end{tabular}

Table 5. Results from the thermal diffusion model using a generic whole-rock $k$ value and glacierspecific bulk $k$ values for dry and moist debris layers

\begin{tabular}{|c|c|c|c|c|c|c|}
\hline \multirow[b]{2}{*}{ Site } & \multirow[b]{2}{*}{ Year } & \multirow[b]{2}{*}{$\begin{array}{c}\text { Debris } \\
\text { thickness (m) }\end{array}$} & \multirow[b]{2}{*}{$\begin{array}{l}\text { Glacier-specific } \\
\text { bulk } k\left(\begin{array}{l}W \mathrm{~m}^{-1}{ }^{\circ} \mathrm{C} \\
1\end{array}\right)\end{array}$} & \multicolumn{3}{|c|}{$\begin{array}{l}\text { Ablation calculated using the thermal diffusion model } \\
\qquad\left(\mathrm{kg} \mathrm{m}^{-2}\right)\end{array}$} \\
\hline & & & & $\begin{array}{l}\text { Experiment } 1 \text { : using } \\
\text { whole-rock value for } \\
k \text { of } 2.5 \mathrm{~W} \mathrm{~m} \mathrm{~m}^{-1} \mathrm{C}^{-1}\end{array}$ & $\begin{array}{l}\text { Experiment } 2 \text {. } \\
\text { using glacier- } \\
\text { specific bulk } k\end{array}$ & $\begin{array}{c}\text { Experiment } 3 . \\
\text { with a moist } \\
\text { debris layer }\end{array}$ \\
\hline $\mathrm{KH} 1$ & 2014 & 1.50 & $0.98 \pm 0.1$ & - & - & 103 \\
\hline $\mathrm{KH} 1$ & 2015 & 1.50 & $0.98 \pm 0.1$ & 380 & 99 & 125 \\
\hline $\mathrm{KH} 2$ & 2014 & 0.70 & $0.98 \pm 0.1$ & 387 & - & 145 \\
\hline $\mathrm{KH} 4$ & 2014 & 0.30 & $0.98 \pm 0.1$ & 1036 & - & 474 \\
\hline NG1 & 2002 & 2.00 & $1.43 \pm 0.14$ & 627 & 325 & - \\
\hline
\end{tabular}


The Cryosphere Discuss., https://doi.org/10.5194/tc-2017-239

Manuscript under review for journal The Cryosphere

Discussion started: 30 November 2017

(c) Author(s) 2017. CC BY 4.0 License.

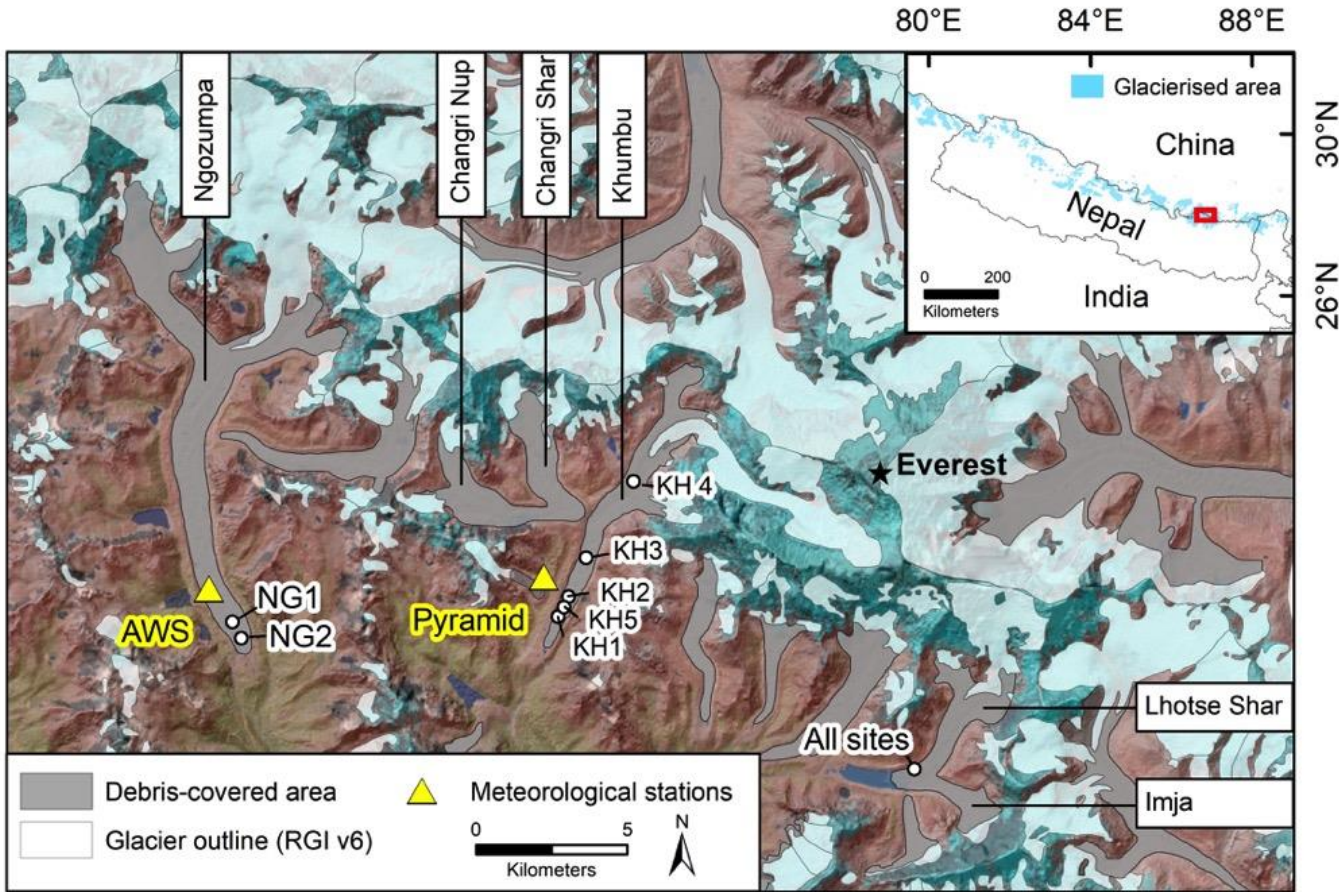

Figure 1. Location map of the Everest region showing the sites where debris temperatures were measured on Ngozumpa, Khumbu and Imja-Lhotse Shar Glaciers. Glacier outlines are taken from the Randolph Glacier Inventory (v6.0; RGI Consortium, 2017), imagery is from Landsat bands 7, 5 and 4 in 2015 . Inset shows the location of the main figure 
The Cryosphere Discuss., https://doi.org/10.5194/tc-2017-239

Manuscript under review for journal The Cryosphere

Discussion started: 30 November 2017

(c) Author(s) 2017. CC BY 4.0 License.

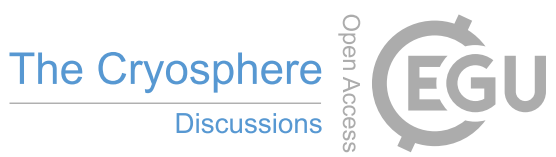

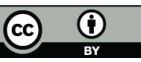

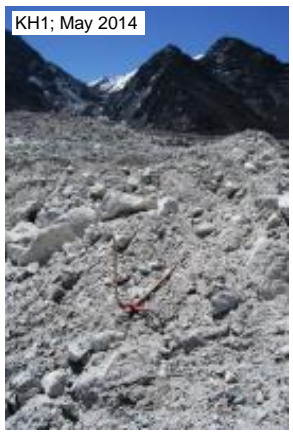
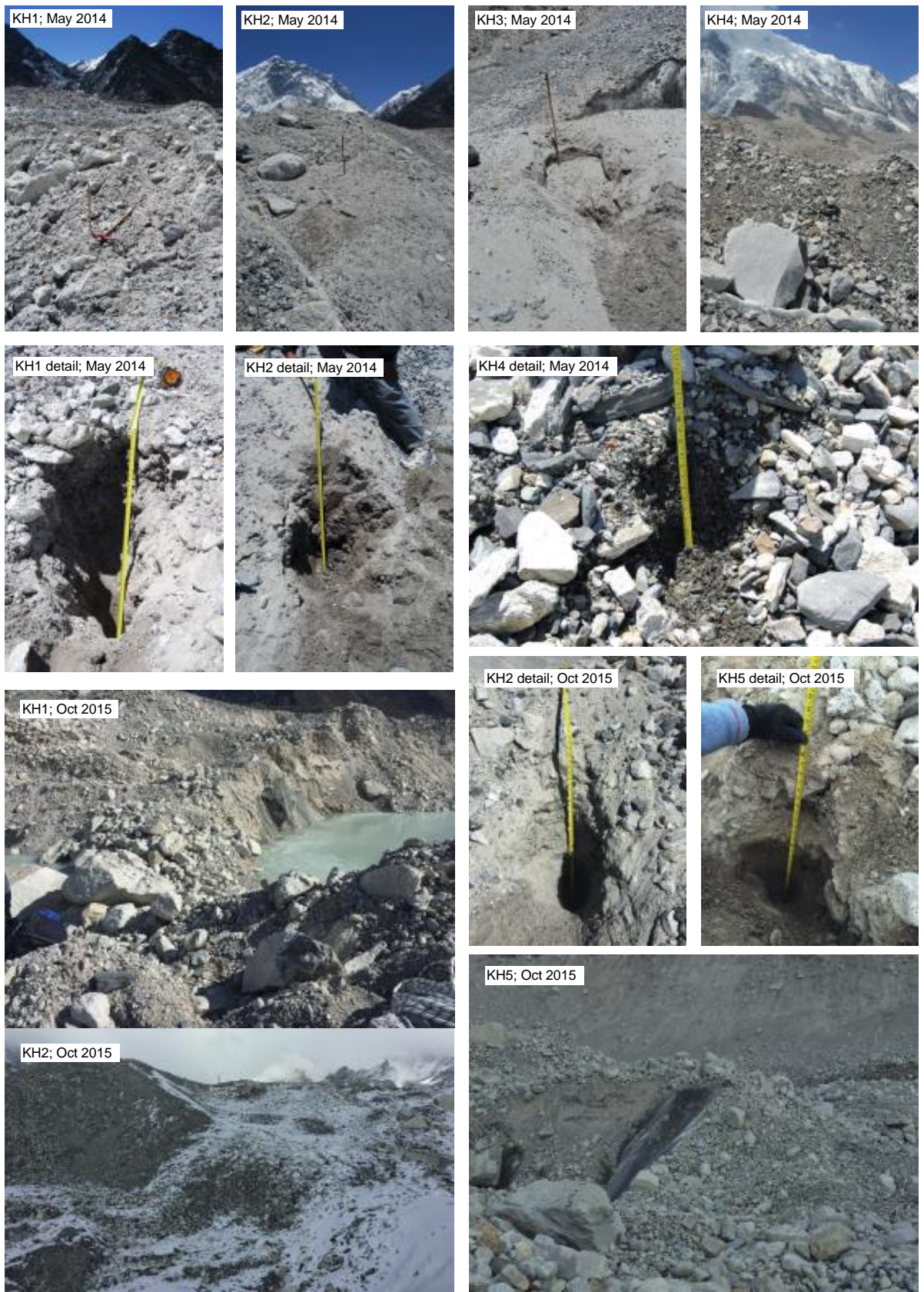

Figure 2. Photographs of the debris profiles measured at each site on Khumbu Glacier, showing an overview of the site and the measured debris profile in detail during excavation before thermistors were emplaced and the debris was returned to the original position. Note that although the debris is coarse at the surface, the subsurface profiles often had a finer grain size distribution. Debris at KH4 was more angular and contained a greater proportion of schist clasts compared to the sites closer to the terminus on Khumbu Glacier which were predominately granitic clasts 
The Cryosphere Discuss., https://doi.org/10.5194/tc-2017-239

Manuscript under review for journal The Cryosphere

Discussion started: 30 November 2017

(c) Author(s) 2017. CC BY 4.0 License.

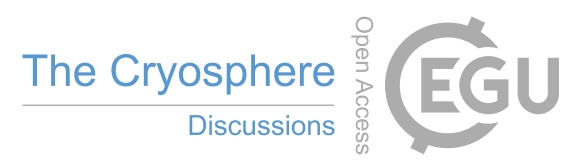

(c) (i)
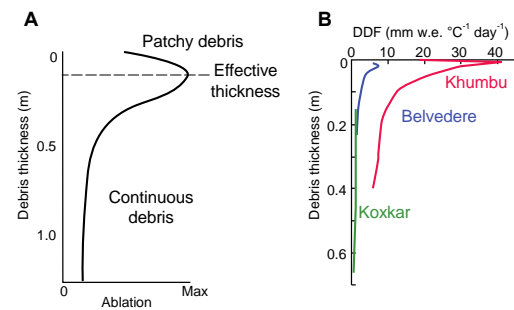

1045

Figure 3: The relationship between supraglacial debris thickness and ablation of the underlying ice. (a) Schematic diagram of the Østrem curve describing the relationship between ablation beneath a debris layer and debris thickness, (b) Østrem curves derived from degree-day factors measured from field observations of three debris-covered glaciers; Belvedere Glacier, Italy (Nicholson and Benn, 2006), Khumbu Glacier, Nepal (Kayastha et al., 2000) and Koxkar Glacier, Tien Shan (Juen et al., 2014) 
The Cryosphere Discuss., https://doi.org/10.5194/tc-2017-239

Manuscript under review for journal The Cryosphere

Discussion started: 30 November 2017

(c) Author(s) 2017. CC BY 4.0 License.
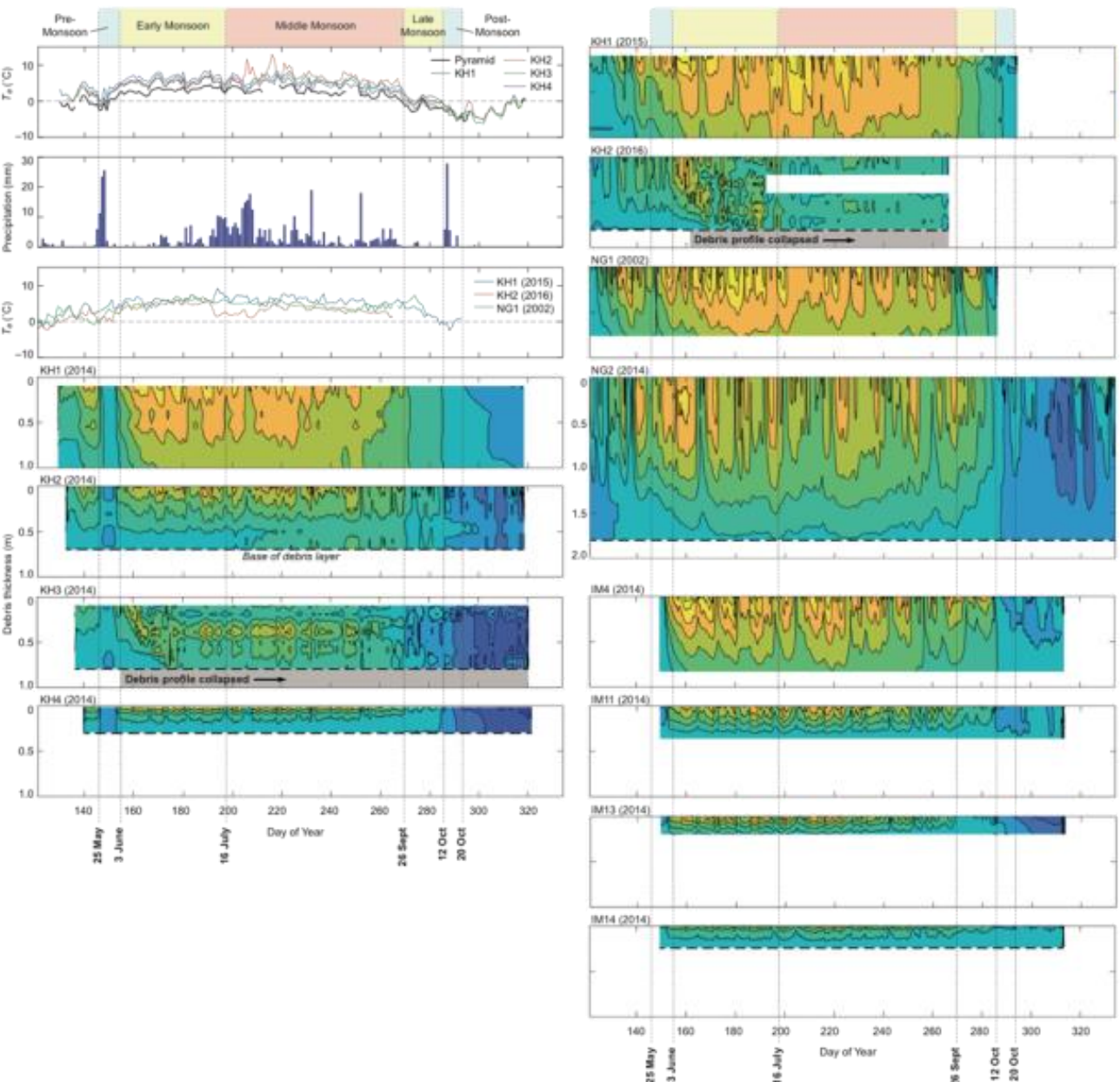

Figure 4. Air and debris temperatures $\left(T_{a}\right.$ and $\left.T_{d}\right)$ measured at each site, showing mean daily $T_{a}$ from each site on Khumbu Glacier and mean daily $T_{a}$ and daily precipitation amount measured at the Pyramid Observatory (rain plus snow as water equivalent). Mean daily $T_{a}$ from KH1 in 2015, KH2 in 2016 and NG1 in 2002. Daily mean $T_{d}$ isotherms for the debris layer during the monsoon season at all three glaciers for the site and year given in the figure. All debris thicknesses are plotted to the same scale and the colourbar scale for $T_{d}$ is the same in each case. A dashed line indicates where the profile reached the debris-ice interface. A grey shaded bar indicates where the profile collapsed during the measurement period. Measurements made at KH5 are not shown, as due to collapse of the debris surface data were only recorded during winter 
The Cryosphere Discuss., https://doi.org/10.5194/tc-2017-239

Manuscript under review for journal The Cryosphere

Discussion started: 30 November 2017

(c) Author(s) 2017. CC BY 4.0 License.

(c) (1)
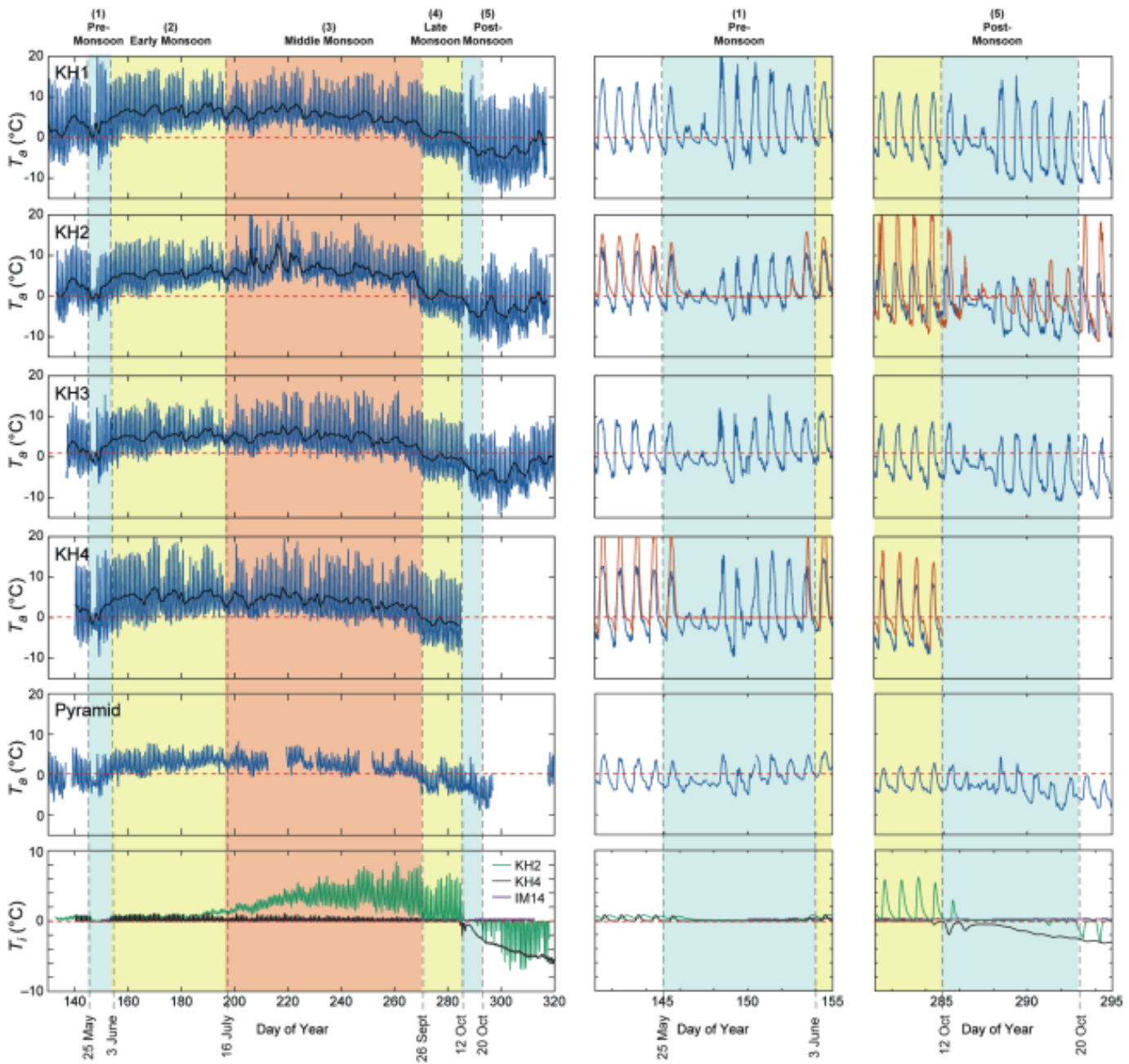

1065

Figure 5. Complete timeseries of $T_{a}$ from Khumbu Glacier and the Pyramid Observatory measured in 2014 at 30 minute intervals (blue line) and mean daily values (black line), and $T_{s}$ (red line) at two sites with the periods identified as the pre-monsoon, monsoon and post-monsoon. Gaps in the Pyramid timeseries indicate where data were not available. The complete timeseries of $T_{i}$ measured at sites $\mathrm{KH} 2, \mathrm{KH} 4$ and IM14 are compared. Note that the profile collapsed at KH2 after 6 June and as a result $T_{i}$ values are higher than expected 
The Cryosphere Discuss., https://doi.org/10.5194/tc-2017-239

Manuscript under review for journal The Cryosphere

Discussion started: 30 November 2017

(c) Author(s) 2017. CC BY 4.0 License.
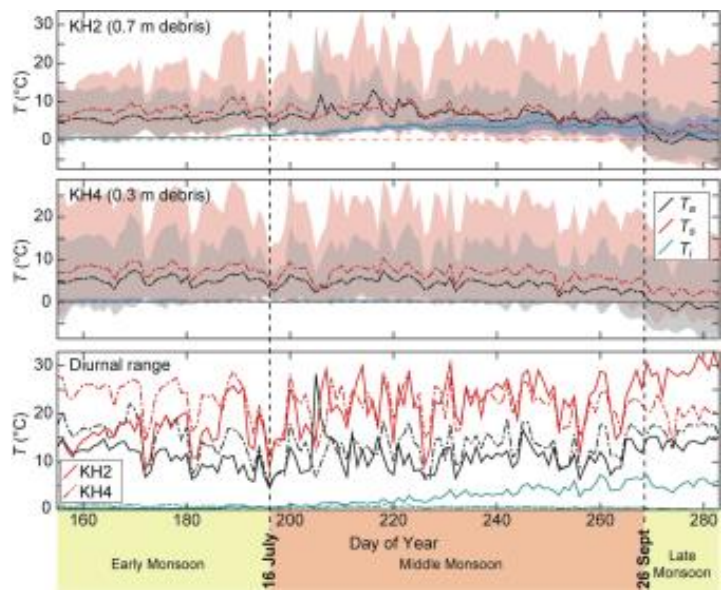

1075 Figure 6. Timeseries of mean daily $T_{a}, T_{s}$ and $T_{i}$ through the 2014 monsoon season at KH2 and KH4. The diurnal ranges are shown by the shaded background and compared in the lowermost plot
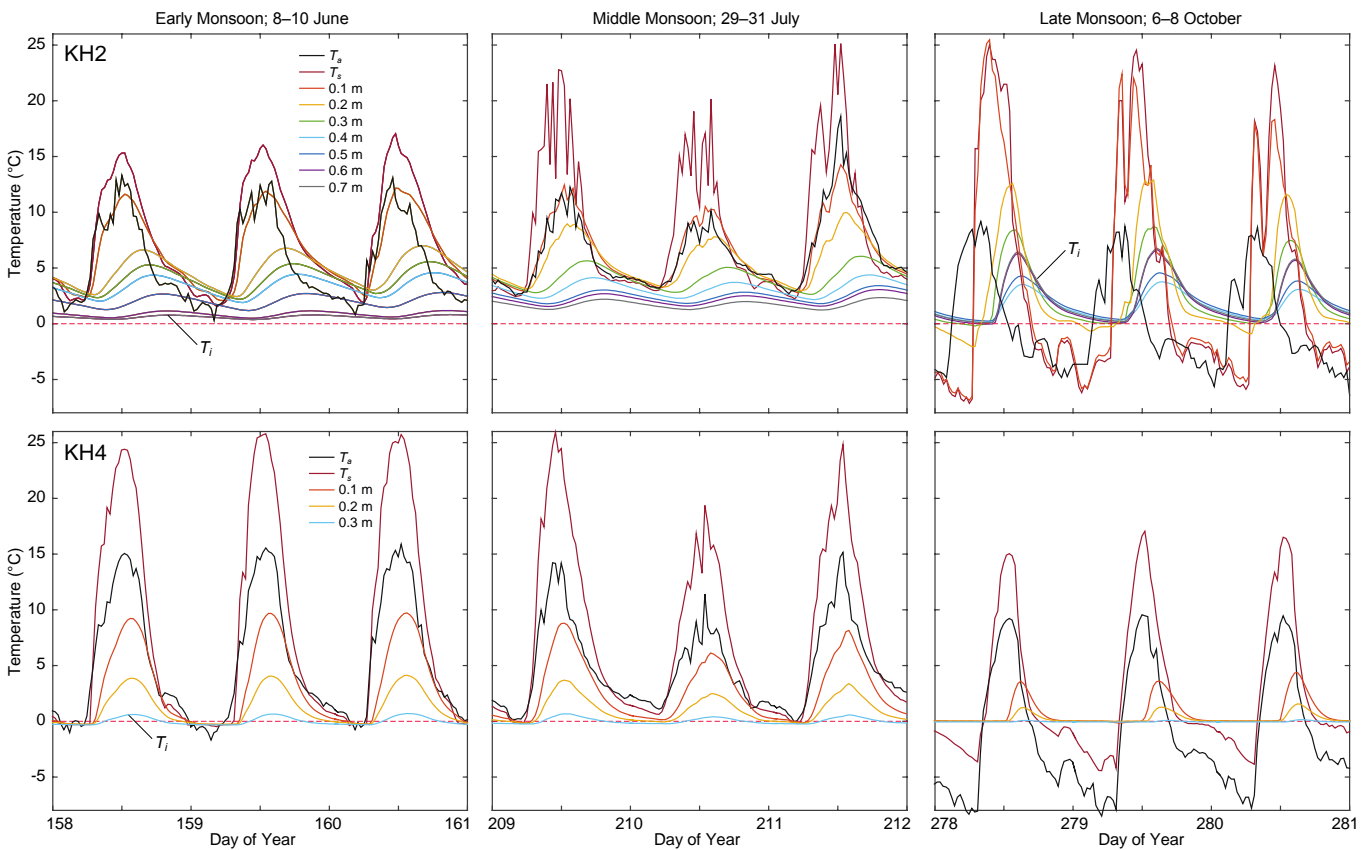

1080

Figure 7. Three-day examples of $T_{a}, T_{s}$, and $T_{d}$ to the debris-ice interface at $\mathrm{KH} 2$ through $0.7 \mathrm{~m}$ of debris and KH4 through $0.3 \mathrm{~m}$ of debris for the early (8-10 June) middle (29-31 July) and late (6-8 October) monsoon season in 2014. Note the difference in lag between $T_{s}$ and $T_{d}$ between the thick and thin debris layers 
The Cryosphere Discuss., https://doi.org/10.5194/tc-2017-239

Manuscript under review for journal The Cryosphere

Discussion started: 30 November 2017

(c) Author(s) 2017. CC BY 4.0 License.

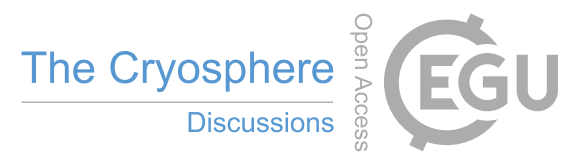

(c) (i)
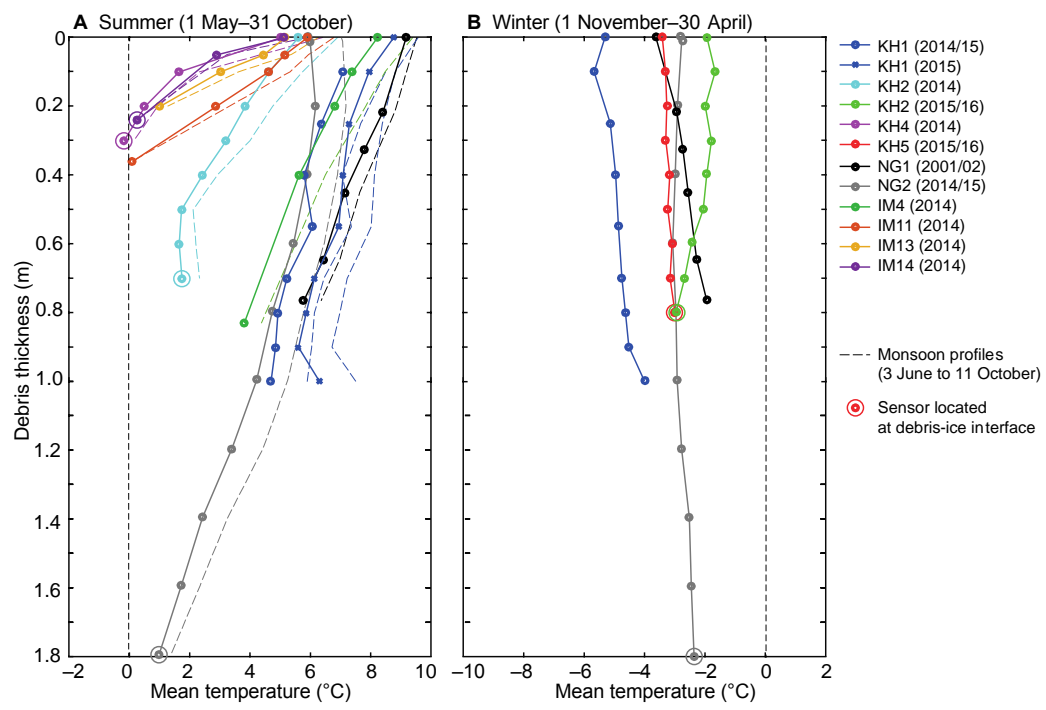

Figure 8. Seasonal $\delta T_{d} / \delta h_{d}$ for Khumbu, Ngozumpa and Imja-Lhotse Shar Glaciers for (a) summer (1 May to 31 October) and the monsoon season (3 June to 12 October; dashed lines) and (b) winter (1 November to 30 April). Where the profile reached the debris-ice interface this is indicated by a circle. The standard deviations of $T_{d}$ are not shown but for summer measurements these values range from $0.8^{\circ} \mathrm{C}$ (KH1) to $2.4^{\circ} \mathrm{C}$ (IM14) and for winter from $0.1^{\circ} \mathrm{C}$ (KH5) to $0.6^{\circ} \mathrm{C}$ (NG1) 
The Cryosphere Discuss., https://doi.org/10.5194/tc-2017-239

Manuscript under review for journal The Cryosphere

Discussion started: 30 November 2017

(c) Author(s) 2017. CC BY 4.0 License.
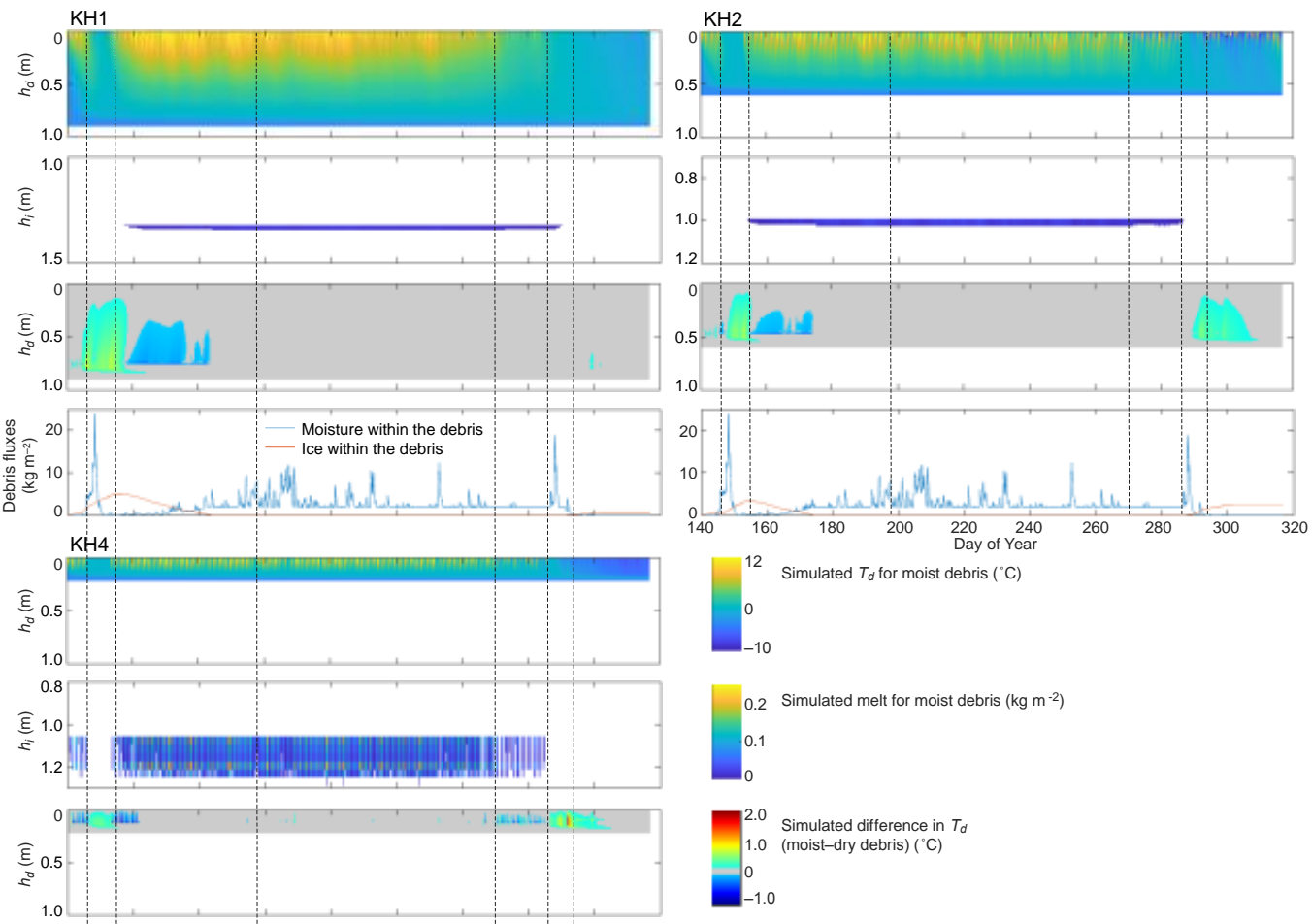

1095

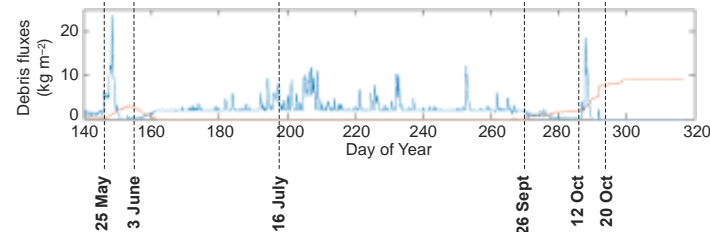

Figure 9. Results of the thermal diffusion model experiments for KH1, KH2 and KH4 in 2014, showing simulated $T_{d}$, simulated sub-debris ablation, the difference in debris temperature resulting from the use of moist or dry debris, and the calculated ice and water contained within the pore space of the debris 
The Cryosphere Discuss., https://doi.org/10.5194/tc-2017-239

Manuscript under review for journal The Cryosphere

Discussion started: 30 November 2017

(c) Author(s) 2017. CC BY 4.0 License.
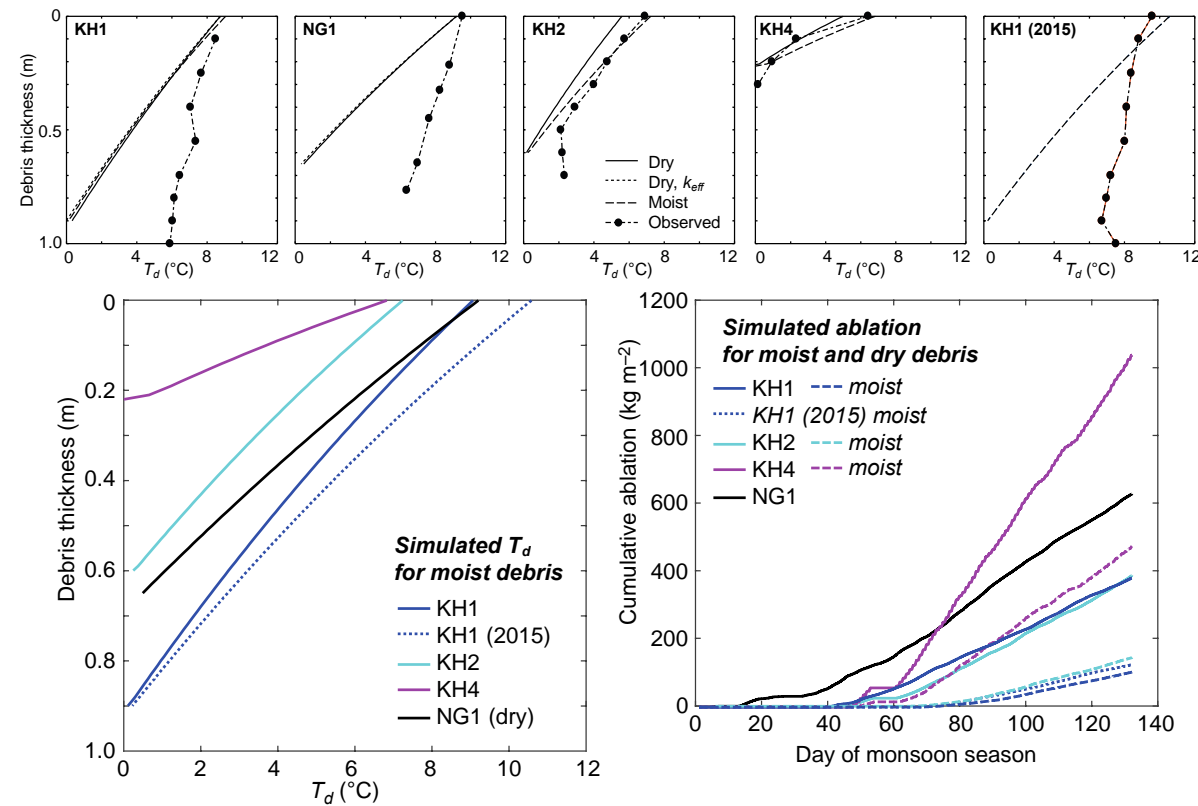

Figure 10. Results from thermal diffusion model experiments showing simulated $\delta T_{d} / \delta h_{d}$ through moist and dry debris compared to observations at KH1 (2014 and 2015), KH2, KH4 and NG1 using a whole-rock $k$ value of $2.5 \mathrm{~W} \mathrm{~m}^{-1}{ }^{\circ} \mathrm{C}^{-1}$ and glacier-specific bulk $k$ values $\left(k_{\text {eff }}\right)$ calculated locally for KH1 (0.977 W m- $\left.{ }^{-1} \mathrm{C}^{-1}\right)$ and NG1 (1.43 $\left.\mathrm{W} \mathrm{m}^{-1}{ }^{\circ} \mathrm{C}^{-1}\right)$ (dashed lines), and the simulated cumulative ablation at each site assuming either a moist or a dry debris layer. Note that where thermistors were not installed at the debris-ice interface at KH1 and NG1 the debris thickness simulated here is a minimum and $T_{d}$ is assumed to be zero at this minimum thickness, such that the model gives an underestimate of ablation for these sites 
The Cryosphere Discuss., https://doi.org/10.5194/tc-2017-239

Manuscript under review for journal The Cryosphere

Discussion started: 30 November 2017

(c) Author(s) 2017. CC BY 4.0 License.

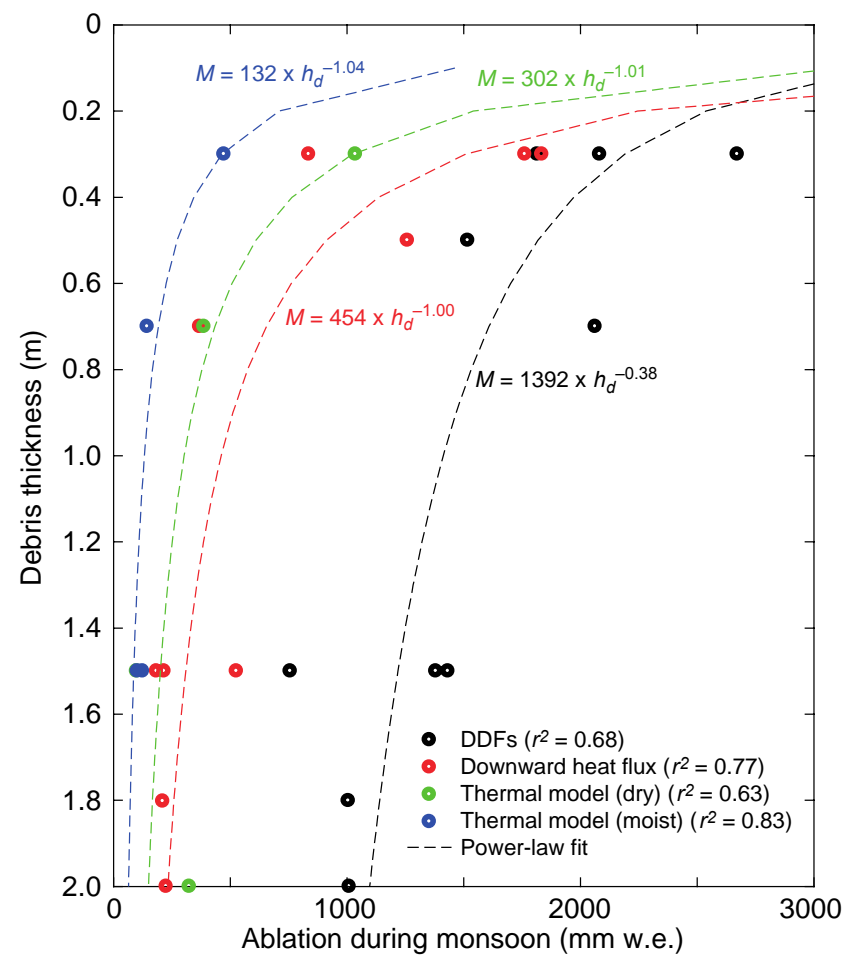

Figure 11. Østrem curves for monsoon-influenced glaciers in the Himalaya, showing the best-fit power-law functions for sub-debris ablation calculated using DDFs, downward heat flux and the thermal diffusion model with dry (Experiment 1) and moist (Experiment 3) debris for 11 sites on three debris-covered glaciers during the monsoon season (3 June to 11 October) 